PONTIFÍCIA UNIVERSIDADE CATÓLICA DO RIO DE JANEIRO

\title{
O uso da remuneração variável como ferramenta estratégica organizacional.
}

\section{Victor Felcman Adesse}

Trabalho de Conclusão de Curso

Centro de ciências sociais - CCS

DePARTAMENTO de AdMINISTRAÇÃo

Graduação em Administração de Empresas 
Victor Felcman Adesse

O uso da remuneração variável como ferramenta estratégica organizacional.

Trabalho de Conclusão de Curso

Trabalho de Conclusão de Curso, apresentado ao programa de graduação em Administração da PUC-Rio como requisito parcial para a obtenção do título de graduação em Administração.

Orientador(a): Andréa Bittencourt

Rio de Janeiro

Dezembro de 2018. 


\section{Agradecimentos}

Primeiramente gostaria de agradecer a uma pessoa em especial que me proporcionou o fato de eu poder estudar na universidade PUCRio, visando sempre o melhor para a minha pessoa. Infelizmente minha avó, Judith Felcman, não está mais conosco presenciando este fim de um ciclo que a mesma sempre lutou.

Em seguida, gostaria de agradecer aos meus pais, Giselle e Ezra Henrique. Sem o apoio, os ensinamentos e o amor que eles me passam eu não teria conquistado isto.

Não posso deixar de enaltecer meus avós. Sr. Elias, meu avô materno, teve participação direta em minha educação. Já minha avó paterna, Dona Sára, é um ícone de ser humano que precisa ser estudado. Não pude conhecer meu avô paterno, mas tenho certeza que o mesmo está bastante orgulhoso.

Gostaria de agradecer também a minha irmã Dhyana, aos meus primos Bruno, Daniel, Dora, Mariana, Nathan e Noah e aos meus tios Eliane, Elisa, Leila, Marcos e Rosane que de alguma forma colaboraram para a formação do meu caráter.

Gostaria de agradecer aos meus amigos que me acompanham desde sempre e a uma pessoa em especial, que é a Júlia.

E por fim, a minha orientadora Andréa Bittencourt, que me auxiliou na realização deste trabalho. 


\section{Resumo}

Felcman Adesse, Victor. Bittencourt, Andréa. O uso da remuneração variável como ferramenta estratégica organizacional. Rio de Janeiro, 2018. 49p. Trabalho de Conclusão de Curso - Departamento de Administração. Pontifícia Universidade Católica do Rio de Janeiro.

A presente pesquisa discute a respeito do tema da remuneração variável, que é um modelo onde o colaborador de uma instituição recebe pelo que o mesmo produz, ao contrário da remuneração fixa que está atrelada ao tempo disponibilizado e tarefas específicas do cargo. Diversos fatores são necessários para definir a estratégia utilizada pelas empresas. O trabalho é pautado em diversos pilares, sendo o principal deles a motivação. O objetivo é comparar o atual modelo mais utilizado com a remuneração variável. Através de um estudo do referencial teórico e de uma pesquisa de campo na qual se conclui que é a melhor estratégia de remuneração a ser utilizada pelas empresas.

Palavras-chave: remuneração variável; estratégia; funcionário, empresas.

\section{Abstract}

Felcman Adesse, Victor. Bittencourt, Andréa. The use of variable remuneration as na organizational strategic tool. Rio de Janeiro, 2018. 49p. Trabalho de Conclusão de Curso - Departamento de Administração. Pontifícia Universidade Católica do Rio de Janeiro.

This research discusses the subject of variable remuneration, which is a model where the employee of an institution receives what it produces, contrary to the fixed remuneration that is tied to the time available and specific tasks of the position. Several factors are necessary to define the use of the strategy to be used by companies. The work is based on several pillars, the main one being the motivation. The objective is to compare the current most used model with variable remuneration. Through a study of the theoretical reference and of a field research in which it is concluded that it is the best remuneration strategy to be used by the companies.

Key-words: variable compensation; strategy; employee; companies. 


\section{Sumário}

1. Introdução 1

1.1. Objetivo final 2

1.2. Objetivos intermediários 2

1.3. Delimitação e foco do estudo 3

1.4. Justificativa do estudo 3

2. Referencial Teórico 4

2.1. O indivíduo dentro das organizações e o capital humano 4

2.2. Motivação no trabalho 6

2.3. O que é remuneração? 11

2.4. O sistema de remuneração variável 13

3. Metodologia 17

$\begin{array}{ll}\text { 3.1. Métodos de pesquisa utilizados } & 17\end{array}$

3.2. Procedimentos e instrumentos de coleta de dados utilizados no $\begin{array}{ll}\text { estudo } & 19\end{array}$

4. Apresentação e análise dos resultados 20

4.1. Descrição e análise dos resultados 20

5. Conclusões 35

$\begin{array}{ll}\text { Referências Bibliográficas } & 37\end{array}$

$\begin{array}{ll}\text { Anexo } 1 & 40\end{array}$ 


\section{LISTA DE FIGURAS}

Figura 1 - Pirâmide de Maslow 7

Figura 2 - Teoria dos dois fatores $\quad 10$

Figura 3 - Gráfico de gênero 20

Figura 4 - Faixa etária da amostra 21

Figura 5 - Cargos e funções 22

Figura 6 - Tipo de remuneração 23

Figura 7 - Tipos de remuneração variável 24

Figura 8 - Remuneração variável X Motivação 25

Figura 9 - Remuneração variável X Resultados 26

Figura 10 - Remuneração variável X Competitividade interna 27

Figura 11 - Remuneração variável X Avaliação de desempenho 28

Figura 12 - Vantagens da remuneração tradicional 30

Figura 13 - Desvantagens da remuneração tradicional 31

Figura 14 - Vantagens da remuneração variável 32

Figura 15 - Desvantagens da Remuneração variável 33 


\section{LISTA DE TABELAS}

Tabela 1 - Satisfação no trabalho 


\section{Introdução}

Gerir uma empresa na atualidade é um grande desafio para qualquer administrador e conseguir juntar os recursos e alocá-los corretamente é apenas uma etapa do longo caminho que será percorrido até a entrega do produto ou serviço final que a empresa oferece ao mercado. Um dos principais pilares de uma organização, de fato, são os recursos humanos. Atrelada a isso, está a remuneração, fator que deve ser cuidadosamente avaliado de forma a representar mais do que um fator motivacional, principalmente, em empresas de um porte maior.

Atualmente, de forma genérica, o mercado brasileiro trabalha com um sistema de remuneração tradicional, onde propende-se a abordar coisas distintas de forma semelhante. É explícito que este padrão tradicional é bastante conservador, deixando uma lacuna considerável quando se trata da estratégia de uma empresa. O mesmo evidencia pouca flexibilidade e objetividade. Em consequência disso, o sistema apresenta uma menor eficácia, prejudicando assim a organização como um todo. Segundo Chiavenato (2004), o pagamento mensal dos empregados reduz riscos tanto para a empresa como para os empregados e desta forma a remuneração fixa continua sendo a mais utilizada nas organizações.

O motivo pelo qual o assunto mereceu ser estudado se deve a alguns fatores. Primeiramente, o fato de as médias e grandes empresas corresponderem a 73\% do PIB (Produto Interno Bruto), ou seja, mais de dois terços do que o país produz em riqueza, fato que não pode ser ignorado.

O problema do estudo está relacionado à ideia do que é mais vantajoso para médios/grandes empreendimentos em relação à estratégia a ser utilizada quando se trata de remuneração dos funcionários. Logo, o problema da presente pesquisa é: $O$ que seria mais motivador aos 
funcionários em uma empresa de médio/grande porte, a remuneração tradicional ou a associação de uma remuneração variável?

Justifica-se pela grande importância que o tema tem na área de administração, além da importância do mercado de trabalho atual.

Sobre a remuneração variável, Neto (2004, p. 24) coloca:

\begin{abstract}
A utilização de remuneração variável não se restringe às grandes empresas. Sua utilização está mais vinculada à ideologia de um fundador que acredita que 0 compartilhamento do sucesso entre os empregados aumenta a produtividade $\mathrm{e}$ os lucros. Dados os benefícios dessa iniciativa, as empresas não devem aguardar o posicionamento do Governo para praticar a distribuição dos lucros. Elas devem começar a encontrar formas de discutir o assunto internamente e entender que não existem empresas fortes com funcionários fracos.
\end{abstract}

Deve ser feito um esforço para promover uma conceituação sólida, após o que se dará uma descrição de aspectos indispensáveis ao estudo da importância da remuneração variável, bem como as diferenças para com a remuneração tradicional.

\title{
1.1. Objetivo final
}

O presente trabalho tem por objetivo entender as razões que incentivam e dão motivação aos funcionários dentro de uma organização, principalmente, e se há relação com o tipo de remuneração paga aos mesmos. A pesquisa buscou investigar de que forma a remuneração tradicional versus variável, afetam a motivação dos colaboradores desse porte de empreendimentos na percepção de pessoas que atuam no mercado de trabalho.

\subsection{Objetivos intermediários}

Com o intuito de colaborar a atingir o objetivo principal da pesquisa, é fundamental evidenciar objetivos intermediários, como:

I. Compreender o papel dos indivíduos dentro de uma organização e sua importância para o capital humano;

II. Pesquisar fatores motivacionais mais relevantes para os funcionários;

III. Conceituar o sistema tradicional de remuneração; 
IV. Levantar as formas de remuneração variável existentes;

V. Aplicar uma pesquisa junto a profissionais que atuam em empresas que adotam ou não a remuneração variável, observando o grau de motivação dos mesmos e se estas se relacionam com o sistema de remuneração adotado.

\subsection{Delimitação e foco do estudo}

Para análise deste estudo, foram abordados empregados de empresas de médio/grande porte sem restrição quanto a natureza da mesma e que fazem uso tanto da remuneração variável quanto da remuneração tradicional. Estas estão localizadas no estado do Rio de Janeiro.

\subsection{Justificativa do estudo}

Este estudo tem uma grande importância para academia, pelo fato de a mesma buscar sempre aprofundar seus estudos em relação a motivação dos funcionários. Vale também destacar a colaboração para as pesquisas em estratégia no âmbito motivacional.

Outra relevância do presente trabalho é o mercado desse porte de empresas. Como vimos anteriormente, representam cerca de $73 \%$ do PIB, mostrando sua força e influência para com o país. Atualmente, qualquer vantagem competitiva que as organizações possam obter pode fazer uma diferença enorme no resultado final. 


\section{Referencial Teórico}

\subsection{O indivíduo dentro das organizações e o capital humano}

Para uma organização obter êxito, esta deve cumprir várias etapas para que tenha um bom reconhecimento no meio que está inserida. Isso é a consequência do somatório de vários fatores que contribuem para que uma empresa alcance seus objetivos. É fato que o principal recurso para tornar isto uma realidade, não é o capital monetário, algo que muitos acreditam que seja. O capital monetário possui sim, uma parcela de importância na estrutura de uma organização. Contudo o principal elemento que move uma empresa rumo ao sucesso é o capital humano. Sem este recurso, é muito difícil colher bons frutos. Fazendo uma analogia com um carro, por exemplo, o ser humano seria o motor do mesmo. Se as organizações não investirem e não motivarem estes indivíduos, é provável que a empresa não consiga atingir sua missão.

O capital humano é composto de indivíduos que colaboram para o crescimento de uma organização, estes podem ser remunerados ou podem ser voluntariados. A empresa deve sempre valorizar e manter as pessoas que são destaque e que trazem resultados satisfatórios ao conjunto como um todo. (CHIAVENATO, 2004)

Dutra (2008) define gestão de pessoas com uma relevância superior, pois está se passa dentro das organizações em sua maioria. Outro ponto importante a ser ressaltado é que a organização não é nada caso não tenha recursos humanos bem preparados. A gerência de indivíduos é uma tarefa que tem como propósito atingir um comportamento que possa alinhar as necessidades dos indivíduos para com as da empresa. 
O papel do indivíduo dentro de uma organização vem sofrendo modificações ao longo das décadas, se antes ele era visto apenas como alguém que era contratado para executar tarefas, hoje, ele é concebido como um ser completo, dotado de diversas características, e subjetividade, de forma que os diversos indivíduos e colaboradores assumem um papel cada vez mais importante dentro de uma organização, deixando de ser apenas um executor de tarefas. (DIAS, CAMARA, NASCIMENTO, 2003)

$\mathrm{Na}$ era atual diante da grande concorrência do mundo globalizado, o capital humano surge como fator de grande importância para uma organização.

Sobre a teoria do Capital Humano, Cunha et al. (2010, p. 5) colocam:

\begin{abstract}
A teoria do capital humano estabelece, portanto, uma explicação importante para a atribuição da educação no aumento da produtividade e como o principal fator de explicação para os diferenciais de renda observados no mercado de trabalho. As evidências empíricas comprovam que ela tende a ser mais importante para países subdesenvolvidos do que para os desenvolvidos, em virtude da má distribuição da educação entre a força de trabalho. Um paradigma da teoria do capital humano é que as pessoas investiriam em si mesmas (saúde, aquisição de informações, educação, etc.), visando retornos futuros, mesmo que estes ganhos não representassem aspectos pecuniários; ou os indivíduos poderiam adquirir mais escolaridade simplesmente por satisfação pessoal. A escolaridade geraria habilidades cognitivas que representariam enorme valor para 0 próprio sujeito, para o mercado e para a comunidade, que retribuiriam com maior remuneração, mobilidade, etc. Elevações nos níveis de capital humano dos indivíduos, no entanto, não geram apenas significativos aumentos na produtividade e nos salários. Elevam também a competitividade das empresas, o bem-estar dos empregados e a vida da comunidade como um todo.
\end{abstract}

Portanto, as pessoas geram capital pra uma empresa, de acordo com a sua competência, formação e criatividade. Dessa forma, o capital humano tem desempenhado grande importância para o desenvolvimento de uma empresa. A empresa que possui um capital humano bem 
desenvolvido está à frente na concorrência, de forma que é o seu papel saber aproveitar o talento humano, descobrir e incentivar competências.

Jaber (2008) coloca que o capital humano constitui toda a habilidade, experiência e conhecimento dos funcionários de forma a gerar capital para a empresa. É um desafio para a empresa saber administrar o capital humano, de forma que independente do cargo ou função do funcionário se o capital humano é bem administrado, ele trará valor para a empresa.

Segundo Chiavenato (2005), este momento inédito e diferente que estamos vivendo, o fator conhecimento está virando o principal pilar que sustenta uma organização. Essa característica é pertencente aos seres humanos. Atualmente, pode ser considerado mais relevante até que 0 próprio capital monetário.

Podemos verificar que os dois autores acima, tanto Jaber quanto Chiavenato, ressaltaram o fator chave que vêm ganhando cada vez mais espaço que é o conhecimento. Isso mostra uma metamorfose positiva que as organizações vêm sofrendo ultimamente. O real valor que o capital humano possui está chegando em seu devido patamar, ultrapassando aos poucos o capital monetário. O resultado disto é uma melhora em todos os aspectos quando falamos em empresa, clientes, produtos/serviços, colaboradores, etc.

\subsection{Motivação no trabalho}

O conceito primário de motivação está alinhado ao esforço individual de um colaborador com o objetivo de cumprir metas préestabelecidas pela empresa, sem ignorar a satisfação individual do indivíduo. É de suma importância que o empregado se sinta confortável e essencial para a empresa, isso só irá geral mais motivação pelo lado do funcionário, ajudando ainda mais a organização por meio de suas habilidades e competências. Vale ressaltar que a motivação não é resultado de apenas do colaborador ser incentivado, mas sim do meio de 
onde o mesmo está inserido e também de sua equipe de trabalho. Atrelada a motivação e ao esforço, há também as necessidades de cada indivíduo que trabalham de forma conjunta para que o colaborador cumpra suas metas organizacionais.

A motivação é um dos fatores que estão associados com o comportamento das pessoas, sendo que motivar é tudo aquilo que impulsiona a pessoa a agir de determinada forma ou manter determinado comportamento. (BASTOS, 2001)

Bernardo (2015) coloca que é possível identificar dois tipos de motivação: as primárias, em que fazem parte os aspectos fisiológicos como fome, impulso sexual, sede, etc. e as motivações secundárias que abrange os impulsos sociais e de auto realização.

A motivação é tema de diversos teóricos, sendo que o mais conhecido foi Maslow que elaborou a pirâmide das necessidades:

\section{Figura 1 - Pirâmide de Maslow}

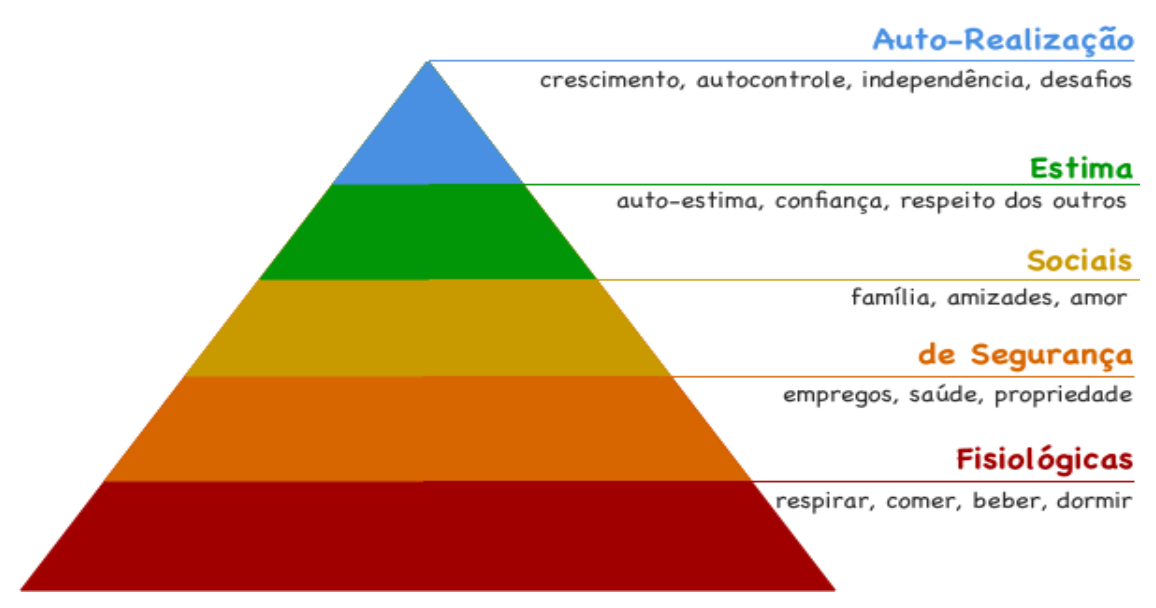

Fonte: https://blog.luz.vc/o-que-e. Acesso em: 26 de outubro de 2018.

Conforme é possível ver na figura, na base da pirâmide estão as necessidades fisiológicas, enquanto no topo estão as necessidades mais complexas associadas com autorrealização. Logo, o colaborador que deseja alcançar a esfera de autorrealização deverá minimamente estar 
satisfeito com as esferas anteriores. Para Maslow, não é possível o empregado ter uma autoestima boa sem ter por satisfeito as condições fisiológicas e de segurança, por exemplo.

No que se refere a motivação no trabalho, Bastos (2001) coloca que é preciso separar fatores individuais dos coletivos.

Sobre os fatores individuais:

A motivação no trabalho é uma tarefa cuja responsabilidade única e total pesa sobre o próprio indivíduo. O processo motivacional na organização sugere que os indivíduos respondam as recompensas e punições. É necessário saber porque o indivíduo escolhe determinada forma de agir, ou por que se move à determinada direção e não em outra. Os administradores quase sempre classificam bons salários, segurança no emprego, promoção e boas condições de trabalho como pontos primordiais que os indivíduos mais desejam. Porém, o trabalhador não concorda com a visão simplista dos administradores, pois o que o indivíduo deseja em seus cargos tende a ser uma apreciação integral do trabalho feito, compreensão dos problemas pessoais, isto é, incentivos que pareçam ligados a motivos de sociabilidade e reconhecimento. (BASTOS, 2001, p. 15)

Sobre os fatores coletivos o autor coloca que está relacionado com o bom relacionamento do funcionário com os colegas de trabalho, seu relacionamento com superiores e chefe, o bom funcionamento de uma equipe de trabalho, dentre outros.

É importante que a empresa motive seus funcionários de forma a promover uma harmonia no trabalho, além do fato de que trabalhador motivado traz benefícios para a empresa. Para que a motivação dos funcionários seja feita de forma efetiva, é necessário que haja dois fatores, os recursos materiais e os humanos. (BASTOS, 2001)

Neto (2004, p. 78) coloca que a satisfação no trabalho está relacionada com a motivação:

A satisfação no trabalho é extremamente importante. Muitos estudos têm demonstrado que ela está relacionada ao comportamento individual de participação e ao comprometimento organizacional. Ou seja, ela é responsável pela boa vontade para continuar 


\begin{abstract}
trabalhando no dia a dia. Ainda que a satisfação não tenha impacto direto no desempenho do trabalho da maioria dos indivíduos, ela pode ser importante no desempenho organizacional, devido aos efeitos na rotatividade do pessoal e no absenteísmo. Por outro lado, quando os empregados afirmam que não estão satisfeitos com o trabalho, significa que eles não vêem consequências positivas associadas ao trabalho e ao fato de continuarem fazendo parte da organização. (NETO, 2004, p. 78)
\end{abstract}

Podemos observar que as condições básicas para se trabalhar, como segurança no trabalho, benefícios sociais e salário não é condição para motivar os funcionários e sim para os mesmos não ficarem desmotivados. A ausência dos mesmos pode gerar insatisfação.

Para Sawrey e Telford (1976, p. 18):

[...] motivo pode ser definido como uma condição interna relativamente duradoura que leva o indivíduo ou que o predispõe a persistir num comportamento orientado para um objetivo, possibilitando a transformação ou a permanência da situação. (apud TAVARES, 2004, p. 2)

O autor acima destaca que a motivação é o que faz com que uma pessoa persista em alguma situação, guiado em busca de um objetivo maior.

A motivação pode ser definida em termos de algum comportamento externo. As pessoas motivadas exercem um esforço maior para desempenhar uma tarefa do que aquelas que não estão, cita FROHMAN (1996).

Conforme Hampton (1990), os fatores de motivação (Os que satisfazem) estão pautados na realização, reconhecimento, o trabalho em si, responsabilidade, avanço e crescimento. De outro modo, os fatores de higiene (os que não satisfazem) estão pautados na administração, política da companhia, supervisão, relacionamento com o supervisor, condições de trabalho, salário, relacionamento com os subordinados, status e segurança.

A teoria dos dois fatores de Frederick Herzberg é dividida em fatores higiênicos que está atrelado a elementos que não motivam os colaboradores, que são: segurança no trabalho, condições físicas de trabalho, relacionamentos interpessoais, salário, política da empresa, supervisão e controle. Estes não são responsáveis por motivar o 
funcionário, os elementos são classificados como básicos para que o empregado não fique insatisfeito aonde está inserido. Já os fatores motivacionais, que são: realização profissional, possibilidade de crescimento/promoção, exercício de responsabilidade, possibilidade de aprendizagem, reconhecimento pelo trabalho realizado são razões que conduzem a extrema satisfação no trabalho, gerando ainda mais motivação ao colaborador e contribuindo para que seu desempenho melhore.

\section{Figura 2 - Teoria dos dois fatores}

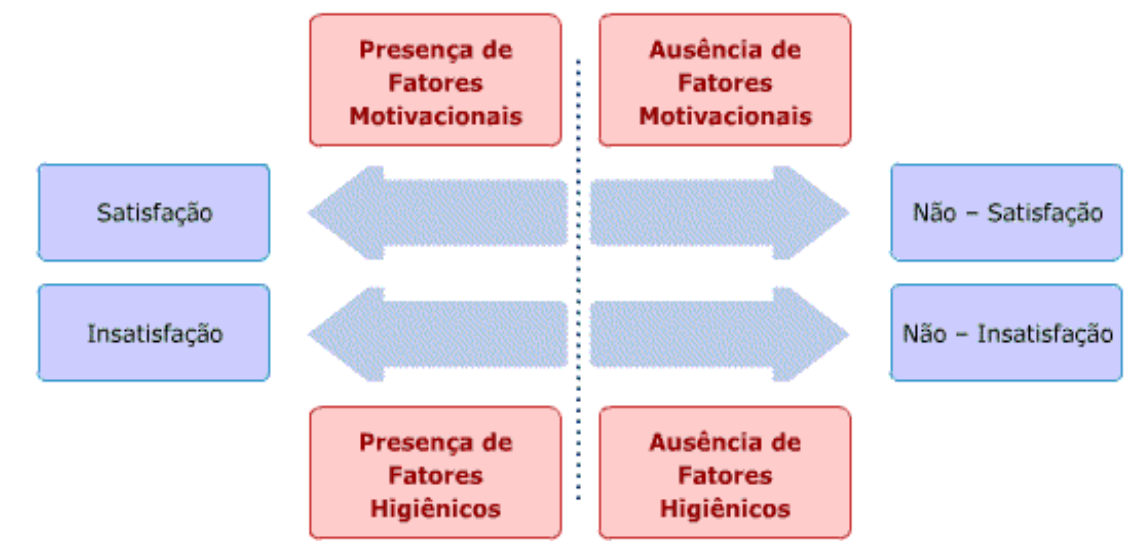

Fonte:http://admteorica.blogspot.com/2016/08/teoria-dos-doisfatores-de-herzberg.html. Acesso em: 04 de novembro de 2018.

Quando comparamos a teoria dos dois fatores de Frederick Herzberg com a teoria da pirâmide de Maslow, podemos observar que ambos abordam o mesmo assunto de forma distinta. As necessidades fisiológicas, de segurança e parte de associação que Maslow coloca remete aos fatores higiênicos que são teorizados por Herzberg. Logo, o topo da pirâmide que são a autorrealização, a estima e parte da associação está atrelado aos fatores motivacionais.

Há também a teoria das três necessidades, esta pode ser considerada uma teoria mais moderna que foi desenvolvida por David McClelland. O primeiro impulso básico no qual se relaciona com 0 comportamento é a necessidade de realização, está relacionado com cumprimento de metas e objetivos mais difíceis, tendo que sempre superar seus próprios limites, realizando atividades bastante 
desafiadoras. Já a segunda é a necessidade de poder, está relacionado a vontade de influenciar indivíduos e ter controle sobre os mesmos. Por fim, há a necessidade de afiliação, relativas a vontade de se associar com outros indivíduos, evitar conflitos e criar relações íntimas. (SOBRAL; PECl, 2008)

Essa teoria remete à necessidade por correspondência. É necessário que ocorra um alinhamento de ideias entre o cargo a ser ocupado e o indivíduo. Por exemplo, uma pessoa que possui necessidade de poder provavelmente irá desempenhar um papel muito melhor em um cargo que exerça controle sobre outros indivíduos. Ou então um indivíduo que é bastante competitivo deve desempenhar tarefas que requer 0 cumprimento de metas, que está relacionado à necessidade de realização.

\section{3. $O$ que é remuneração?}

A remuneração é tudo aquilo que um colaborador de uma organização recebe ao final de um período trabalhado, podendo ser capital monetário ou não, sendo que este deve ser acordado junto ao empregador antes de começar o exercício de sua função. Hoje em dia, basicamente, existem três tipos de remuneração. O primeiro sistema é a remuneração fixa, no qual o funcionário sabe o quanto irá ganhar ao final do período trabalhado; em seguida, há o sistema de remuneração variável, no qual este varia em relação a diversos outros fatores, como por exemplo o desempenho; e por fim, existe a remuneração mista, onde o colaborador recebe um fixo e dependendo de alguns elementos a remuneração pode mudar de acordo com critérios preestabelecidos junto ao empregador.

Para Chiavenato (2004), "a remuneração constitui tudo quanto o empregado aufere como consequência do trabalho que realiza em uma organização" (apud FAVARIM, 2011, p. 4)

Segundo Martins (2008), a remuneração é composta de todos os elementos que a empresa oferece ao colaborador, podendo ser monetário ou não, em razão do serviço prestado resultante da firmação de um 
tratado formal, podendo ser firmado por meio do empregador ou até mesmo por terceiros, podendo ser também na forma de gratificação, desigual ao salário, que é o valor pago aos ocupantes de um cargo, independente da atuação individual do empregado.

De acordo com Favarim (2011, p. 6):

Partindo dessa premissa, a remuneração pode ser composta de uma parte fixa, considerada estável, onde sua existência é condicionada a diversos fatores que estão diretamente relacionadas com a pessoa do empregado dentro da organização, na ocupação de um cargo. (FAVARIM, 2011, p. 6)

O sistema tradicional ainda é muito utilizado, neste sistema são utilizadas descrições de cargos, e salários que permitem que a corporação mantenha uma organização, entretanto, atualmente há muita discussão sobre os problemas decorrentes dessa forma de remuneração. Sendo que uma das principais falhas desse sistema é tratar tudo de forma homogênea, ou seja, não leva em consideração as particularidades de cada cargo e função. (NETO, 2004, p. 13)

Não há consideração adequada das peculiaridades de cada uma das áreas e funções, ou seja, há inflexibilidade e pouca objetividade. Também é trabalhoso, pouco ágil, de manutenção difícil e requer muito tempo para reavaliação de cargos, principalmente os multifuncionais, além de oferecer dificuldade para se focar os processos, os resultados críticos e os clientes, e de apresentar uma vida curta em função da dinâmica organizacional. Pode-se dizer ainda que o sistema tradicional de remuneração é estático, têm eficácia reduzida, não considera a visão do futuro nem a dinâmica da orientação estratégica da organização e causa séria dificuldade para a convergência dos esforços para os objetivos comuns. Muitas vezes, representa um entrave à evolução e às mudanças, por não incentivar o perfeito ajustamento das ações de cada profissional com os objetivos estratégicos da organização. (NETO, 2004, p. 13)

O autor coloca basicamente que este sistema de remuneração é algo que deveria ser obsoleto pelo seu modo de uso, digamos burocrático, de tratar as coisas. Vale também ressaltar que quando a eficácia de um processo é reduzida, isso gera uma decorrência enorme a outros setores que compõe a organização como um todo, como por exemplo os resultados da mesma. 
As empresas vêm sofrendo intensas mudanças no processo de gestão, o que faz com que o modelo tradicional de remuneração seja repensado, de forma que é um desafio fazer com que a remuneração do colaborador seja um fator motivador, que possa trazer transformações para a empresa. É importante que o desempenho, a criatividade e o diferencial do indivíduo seja valorizado através da remuneração dentro de uma empresa. Portanto, o funcionário deixa de ser apenas uma parte da pequena do processo produtivo e passa a ter uma grande importância no processo como um todo. (ROSA, 2000)

De acordo com Ribeiro (2006, p. 311):

O trabalho nem sempre foi remunerado, inicialmente havia a troca de prestação de serviço por sal, pois este ajudava na conservação dos alimentos, posteriormente essa troca passou a ser por mercadorias diversas e finalmente chegou-se a troca do trabalho pela moeda. Dessa forma, a palavra salário vem do latim solarium, que significa pagamento com sal. (apud FAVARIM, 2011, p. 2)

Tendo em vista o comentário do autor acima, podemos enaltecer a evolução que o ser humano teve ao longo de sua história. Hoje, o sal, não é mais visto como era antes. Isso nos faz pensar que a forma de remuneração, atualmente estabelecida em grande parte das organizações, já está sofrendo mudanças significativas. O desempenho exercido pelos colaboradores de uma companhia deve ser mensurado cada vez mais pela remuneração que o mesmo recebe, deixando em segundo plano o fator tempo, que o mesmo exerce e que nos dias de hoje é o que compõe de forma abusiva a remuneração do funcionário. Ou seja, o tempo não é fator determinante para trazer mais resultados a uma empresa e sim o desempenho do indivíduo.

\subsection{O sistema de remuneração variável}

O conceito de remuneração variável tem como pilar principal o fator justiça. Isso porque o mesmo remunera o colaborador por meio de atividades executadas, sejam elas de qualidade ou não, fazendo com que o esforço e o empenho de determinados funcionários possam ser melhor reconhecidos pela organização, resultando em um aumento na 
remuneração destes, uma vez que, quanto melhor for o resultado que o indivíduo traz para a empresa, mais bem remunerado ele será. No caso de funcionários que não cumpram as metas previamente estabelecidas para com a empresa é completamente inviável que este ganhe o mesmo que um colaborador que obteve um resultado expressivo.

A visão de Marras (2012, p. 3) sobre remuneração variável:

É todo o sistema remunerativo cujo valor final varia em conformidade às metas alcançadas, vis-à-vis aquelas que foram previamente planejadas, sejam elas de caráter quantitativo ou qualitativo. (MARRAS, 2012, p. 3)

A abordagem de Marras se refere ao cumprimento de metas, que foram discutidas e negociadas entre empresa e colaborador previamente. O Objetivo principal tem como base melhorar a motivação dos funcionários e em consequência, aumentar os resultados da organização por meio do melhor desempenho dos mesmos.

Para Flannery, Hofrichter e Platten (1997):

[...] a remuneração flexível pode assumir diversas formas, tais como incentivos individuais a colaboradores-chave, incentivos a pequenos grupos ou equipes de projeto, programas de reconhecimento, incentivos de longo prazo ou participação acionária, participação nos lucros e participação nos ganhos e resultados. (apud MARTINS; VERIANO, 2004, p. 1)

Os autores acima tratam a teoria da remuneração variável de forma mais ampla, visando inclusive o longo prazo, muito por meio da participação acionária que faz com que o colaborador vire um dos proprietários da companhia.

Uma das vantagens da remuneração variável, é o fato de transformar o custo fixo em algo variável e promover uma melhora no desempenho do funcionário, pois ele se torna coproprietário da empresa, de forma que é do seu interesse um aumento dos lucros, melhora da produção, além de aumentar o nível de comprometimento e satisfação do funcionário, o que só gera benefícios para a empresa. (NETO, 2004)

Pontes (2011) tem uma visão mais tática a respeito do tema em pauta, o autor comenta que a remuneração flexível, desde que esteja ligada aos interesses organizacionais, é a melhor forma de remuneração 
estratégica, pois estimula o 'ganha-ganha' organizacional no que se refere as competências individuais dos ocupantes dos cargos estratégicos.

Lawler (2000, p. 69) explica a importância da remuneração por desempenho:

[...] talvez o mais forte argumento para a criação de um sistema de remuneração por desempenho está no fato de que o dinheiro é a única commodity. Ele é relativamente fácil de distribuir, é valorizado pela maioria dos indivíduos, pode ser dado na maioria das formas e existe em toda sociedade organizada. Além disso, é algo que todos esperam receber quando trabalham para uma organização, exceto os casos altruístas, voluntários e filantrópicos. Na verdade, uma organização de negócios que aufere resultados não consegue operar sem distribuir dinheiro a seus empregados. Essa distribuição não deve ser baseada, nem completamente, nem parcialmente, no valor do capital humano. As pesquisas indicam que a distribuição de pelo menos parte do dinheiro segundo o desempenho contribui para a eficácia da organização. Especificamente nessas condições, ele parece ser justo e motivador. (apud NETO; MARQUES, 2004, p. 8)

O autor coloca que o fator desempenho é fundamental para motivar os funcionários. Isso se explica pelo fato de que se o colaborador se doar cada vez mais, tendo um desempenho melhor isso vai resultar em um reconhecimento explícito por parte da organização para com o funcionário e em consequência disto, gera uma motivação mais ferrenha do mesmo, pois este sempre irá em busca de mais reconhecimento.

Neto $(2004$, p. 52) comenta as reflexões sobre a remuneração variável:

O sistema de remuneração se presta a direcionar o comportamento individual e organizacional, bem como criar valores, influenciar as mudanças nos processos e estruturas segundo os objetivos e resultados que se pretende alcançar. Mais especificamente, ele se presta a atrair, incentivar, gerenciar, desenvolver e reter os talentos estratégicos necessários às organizações na busca de objetivos individuais e organizacionais. Por isso, ele deve ser dinâmico, ajustando-se continuamente às mudanças do ambiente. (NETO, 2004, p. 52)

O autor acima ressalta a importância de haver um alinhamento tanto das necessidades quanto de ideias do funcionário para com a organização. Isso porque quando acontece este fenômeno, a organização tende a crescer de forma substancial. É válido enaltecer que o dinamismo 
deve ser fundamental para a adaptação de novas ideias que o mercado sugere.

Segundo Joel Dutra (2016), há basicamente quatro tipos de remuneração variável. São elas, participação nas vendas; participação nos resultados; participação nos lucros; e participação acionária. É possível que a empresa ofereça um modelo combinado a seus colaboradores. Vale também destacar dois pontos fundamentais. Primeiramente é a origem do capital a ser partilhado, que deve ser negociado. O objetivo é incentivar os indivíduos a obterem um lucro acima do que os mesmos estariam dispostos caso não existisse a remuneração variável. Em segundo, é a forma de distribuição, que deve ser negociada em função do desempenho organizacional ou de uma determinada área.

A participação nas vendas é pautada no modo de comissão sobre as vendas de um determinado serviço ou produto comercializado pela organização. Ou seja, caso o vendedor não tenha exercido bem sua função ele terá uma diminuição da sua comissão.

Com relação a participação nos resultados o mesmo se resume em objetivos previamente discutidos entre a empresa e o colaborador. $\mathrm{O}$ propósito da participação nos resultados tem como base aumentar a motivação, melhorar a renda dos funcionários, auxiliar os empregados a atingirem suas metas e por fim maximizar a utilização dos recursos, como capital humano e visando sempre a diminuição dos custos.

Já a participação dos funcionários nos lucros da empresa a remuneração é uma parte dos lucros obtidos pela organização. $O$ objetivo é visar o alinhamento das estratégias da empresa com a dos funcionários. A mesma só acontece quando determinadas metas pré-estabelecidas são realizadas.

Para finalizar, há também a participação acionária, que se resume na distribuição de ações da empresa para os colaboradores quando os mesmos atingem determinados resultados estabelecidos previamente junto à organização. O propósito desse tipo de remuneração é fazer com que os funcionários se preocupem também a longo prazo. Caso a empresa não exerça um papel adequado o colaborador também perde. 


\section{Metodologia}

\subsection{Métodos de pesquisa utilizados}

A metodologia consiste em uma variedade de parâmetros a partir da qual se viabiliza a realização de pesquisa científica de modo organizado, bem delimitado e criterioso, gerando soluções para os problemas levantados, hipóteses confirmadas/refutadas e objetivos sólidos, pertinentes e que se adequem ao estado da questão em que o problema se insere (FONSECA, 2002).

Conforme Severino (2002, p. 57), a metodologia consiste em:

[...] um conjunto de métodos ou caminhos percorridos na busca do conhecimento, sendo assim, a pesquisa é um conjunto de procedimentos sistemáticos fundamentados no raciocínio lógico, objetivando encontrar soluções para problemas propostos, mediante utilização de métodos científicos.

Devido à natureza da proposta que ora se apresenta, recorrer-se-á metodologicamente à revisão bibliográfica para a promoção de um estudo básico teórica-conceitual e qualitativo fundamentado em artigos científicos, demais produções científico-acadêmicas.

A busca online do "Sciello" e "Google acadêmico". Os artigos eletrônicos foram selecionados por meio dos descritores "motivação no trabalho", "remuneração tradicional" e "remuneração variável".

Os critérios de inclusão foram: artigos que retratassem a temática presente nas bases de dados, em português e relacionados aos descritores selecionados. Critérios de exclusão: artigos que não retratassem a temática escolhida e que não estivessem associados aos descritores selecionados.

Os dados foram avaliados através de interpretação, análises e comparações de visões contrastantes de autores acerca dos assuntos trabalhados. O objetivo foi produzir, ao fim, conclusões acerca dos 
objetivos aqui elencados em âmbito teórico e através de uma pesquisa de campo.

Segundo Gomes (2003), através da análise é possível encontrar respostas para as questões formuladas, e afirmações estabelecidas antes do trabalho de investigação.

Em relação a taxonomia a ser utilizada, Vergara (1998):

[..] propõe uma taxonomia para classificar os tipos de pesquisa, segundo dois critérios básicos: quanto aos fins e quanto aos meios de investigação. Essa pesquisa é classificada quanto aos fins, como sendo exploratória e quanto aos meios de investigação, como pesquisa de campo [..] (apud MENDONÇA; MAIA; GÓES, 2004, p. 5)

Quanto aos meios, a pesquisa é classificada como bibliográfica, objetivando analisar e explorar contribuições teóricas já existentes, verificando a literatura disponível a respeito do tema. Esta pesquisa também inclui uma pesquisa de campo com abordagem quantitativa, pois os dados foram tratados de forma estatística, fundamentada em um questionário. Ou seja, a pesquisa como um todo é classificada como pesquisa bibliográfica exploratória quantitativa e qualitativa.

Seguindo ensinamentos de Richardson (1989), "este método caracteriza-se pelo emprego da quantificação, tanto nas modalidades de coleta de informações, quanto no tratamento dessas através de técnicas estatísticas, desde as mais simples até as mais complexas." (apud DALFOVO; LANA; SILVEIRA, 2008, p. 7)

Com relação ao viés qualitativo, este tipo de abordagem analisa os dados em busca de sua essência, explicando sua origem, mudanças e relações, permitindo um resultado ou ponto de vista. (Triviños, 1987)

Quanto aos fins, a pesquisa é teórica-conceitual, porque a mesma está encontrando relações entre seus fatores e componentes já estudados. Explorando o tema para se obter maior entendimento havendo diversas explicações e análises para o mesmo tema, ampliando os conhecimentos para o estudo. 


\subsection{Procedimentos e instrumentos de coleta de dados utilizados no estudo}

O colhimento de dados se deu a partir do método de questionário (anexo I), realizado através da plataforma 'qualtrics', composto por 14 perguntas. O número de entrevistados foi de 208 , todos os indivíduos acima de 18 anos de idade. Foi executado no período de 3 dias, entre o dia 06 de novembro de 2018 até o dia 08 de novembro de 2018. Segundo Carnevalli e Miguel (2001, p. 4) "O questionário é um conjunto de perguntas, que a pessoa lê e responde sem a presença de um entrevistador. Ele pode ser enviado via correio, fax, Internet, etc."

O objetivo do questionário foi observar a visão dos indivíduos que estão no mercado de trabalho a respeito da remuneração variável. Se esta é uma estratégia viável para ser executada de forma mais abrangente nas organizações, em busca de melhores resultados tanto organizacionais, quanto individuais. 


\section{Apresentação e análise dos resultados}

\subsection{Descrição e análise dos resultados}

A amostragem da pesquisa de campo foi realizada com 208 respondentes, dos quais 104 foram do gênero feminino e 104 do gênero masculino, não havendo nenhum entrevistado classificado como 'outros'. Ou seja, no quesito gênero $50 \%$ é do público feminino e $50 \%$ é do público masculino.

Figura 3 - Gráfico de gênero

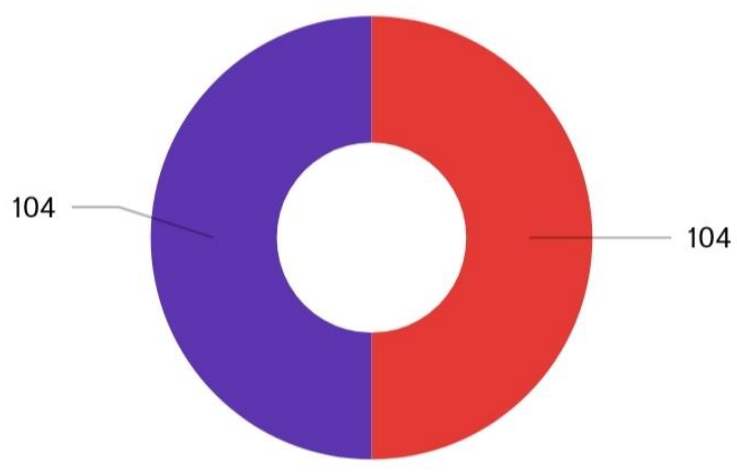

Fonte: Elaborado pelo autor, 2018.

Outro ponto interessante a ser observado é a faixa etária do público entrevistado. Se destacaram os mais jovens com idade de 21 a 25 anos, representado por $25,48 \%$ e os mais velhos, com 56 anos ou mais representado por $16,83 \%$. Vale ressaltar também que a faixa etária que menos participou da pesquisa de campo foram os indivíduos até 20 anos. Podemos concluir que há uma enorme variedade na idade dos 
respondentes, ou seja, a pesquisa conseguiu atingir a diversas faixas etárias.

\section{Figura 4 - Faixa etária da amostra}

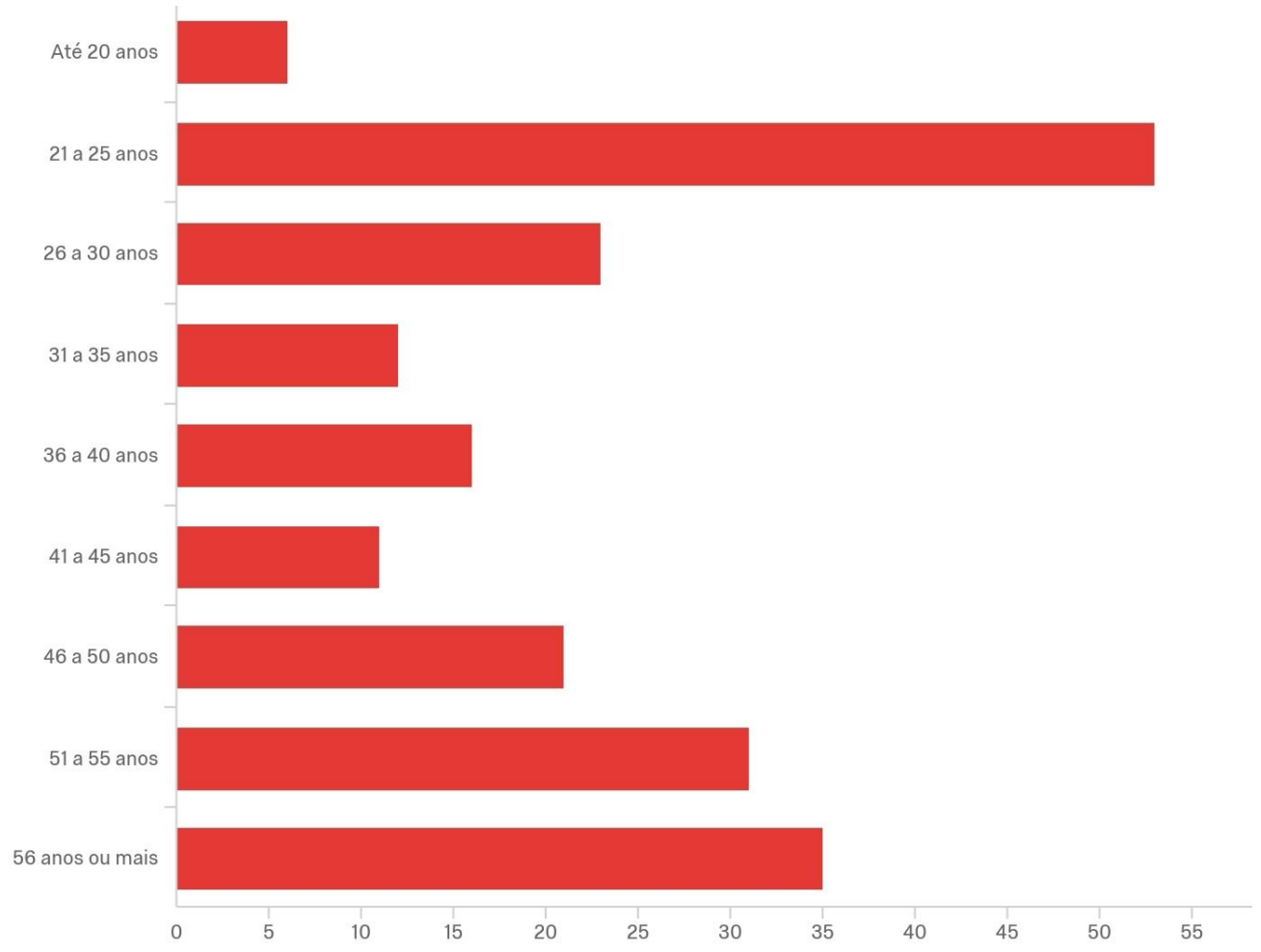

Fonte: Elaborado pelo autor, 2018.

Em seguida, foi questionado a respeito da posição do cargo do indivíduo na organização onde o mesmo trabalha. Essa pergunta é necessária para sabermos com que tipo de público estamos trabalhando, se é mais voltado a pessoas que trabalham na operação da empresa ou até indivíduos que trabalham com um papel mais estratégico dentro da organização.

Podemos observar a seguir que a pesquisa conseguiu atingir a todas as esferas do tipo de trabalho executado, sendo a menor delas a posição de cargo tático, onde o mesmo tem como objetivo examinar determinadas áreas de resultado, como funções empresariais, ter uma visão por unidades de negócios ou departamento e um viés a médio prazo. (Terence, 2002) 
Em relação à maior posição de cargo respondente, que foi o nível operacional, correspondendo a $46,64 \%$, podemos constatar que este provavelmente está alinhado aos jovens de 21 a 25 anos que foi maioria na entrevista realizada. Segundo Terence (2002), o nível operacional pode ser definido como ter um papel com atividades mais rotineiras, definindo propósitos e resultados específicos, executando tarefas que são voltadas ao curto prazo.

Por fim, com $38,46 \%$, vem o setor estratégico das organizações. Este é responsável por cuidar a médio e principalmente a longo prazo, analisando o ambiente interno e externo da organização, coordenando os níveis operacional e tático para que possa executar de forma responsável a estratégia a ser traçada por toda organização.

Logo, podemos constatar que a pesquisa não foi guiada apenas por um tipo de nível hierárquico. Todos os níveis tiveram sua parcela de colaboração para que a pesquisa tomasse um rumo com viés que representasse todos os três níveis acima citados, o que só tende a enriquecer a análise dos resultados para conseguir responder o problema da presente pesquisa.

\section{Figura 5 - Cargos e funções}

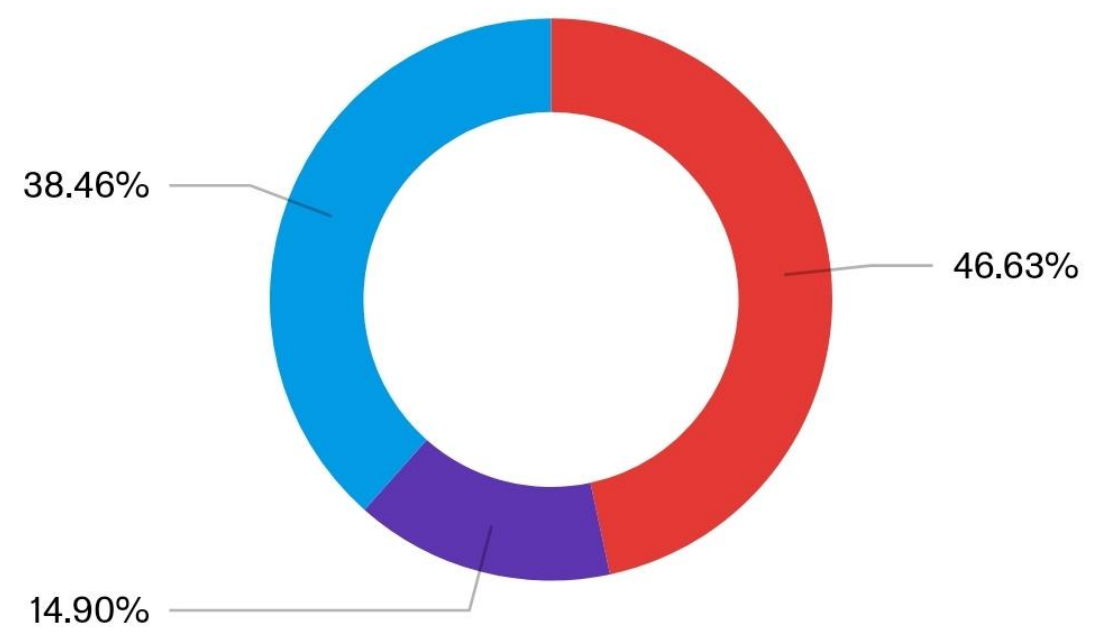

Operacional Tático Estratégico

Fonte: Elaborado pelo autor, 2018. 
Em seguida, a pergunta que foi feita aos entrevistados foi o tipo de remuneração que os mesmos recebiam em suas empresas, sendo elas a remuneração tradicional, que é composta apenas por um valor fixo no qual o colaborador já sabe quanto irá ganhar ao final do período trabalhado; a remuneração variável, esta pode variar de acordo com vários fatores que deverão ser previamente estabelecidos junto ao empregador e pôr fim a remuneração mista, onde o empregado recebe um salário fixo, mas atrelado a isto existe uma remuneração que varia, podendo melhorar o montante a ser recebido.

Podemos observar que atualmente a remuneração fixa corresponde a quase a metade das respostas de nossa amostra, chegando em $48,33 \%$. Isso significa que a prática da remuneração tradicional ainda é predominante nas organizações, o que para muitos autores significa um atraso. Neto, por exemplo, fala que 'não existem empresas fortes com funcionários fracos', ele se refere a pouca competitividade interna que a remuneração fixa traz à organização. Vale ressaltar que a falta de incentivo (ex: participação nos lucros) e o não desenvolvimento dos funcionários é uma forma de perder talentos, situação que é propícia a acontecer este tipo de coisa.

\section{Figura 6 - Tipo de remuneração}

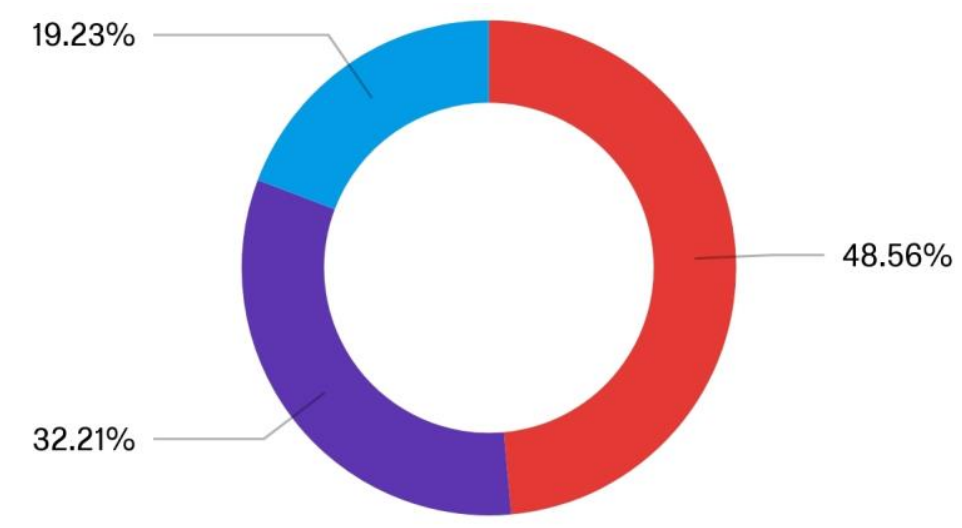

\section{Fixa Variável Mista}

Fonte: Elaborado pelo autor, 2018. 
Podemos verificar que a remuneração variável é maior abordada nas organizações do que a própria remuneração mista, onde 0 colaborador recebe tanto uma remuneração fixa quanto uma remuneração variável. Fato que deve ser investigado posteriormente, tendo em vista que as organizações do nosso público possuem mais práticas conservadoras, o que deveria ser um crescimento por etapas, passando primeiro para uma remuneração mista e depois para um crescimento da remuneração variável.

De fato, é surpreendente que o uso da estratégia da remuneração variável chegue aos $32,21 \%$. Entretanto, o que a pesquisa de campo indica é que ocorra um aumento desta porcentagem.

Após ter sido feita esta pergunta, questionamos o tipo de remuneração variável caso o entrevistado tenha respondido as opções 'variável' ou 'mista' da questão anterior. Constatamos que a forma de remuneração variável mais utilizada nas organizações foi a participação nos lucros, com $30,56 \%$, onde o colaborador recebe uma parcela representativa dos lucros de acordo com 0 que 0 indivíduo/setor colaborou junto à empresa.

\section{Figura 7 - Tipos de remuneração variável}

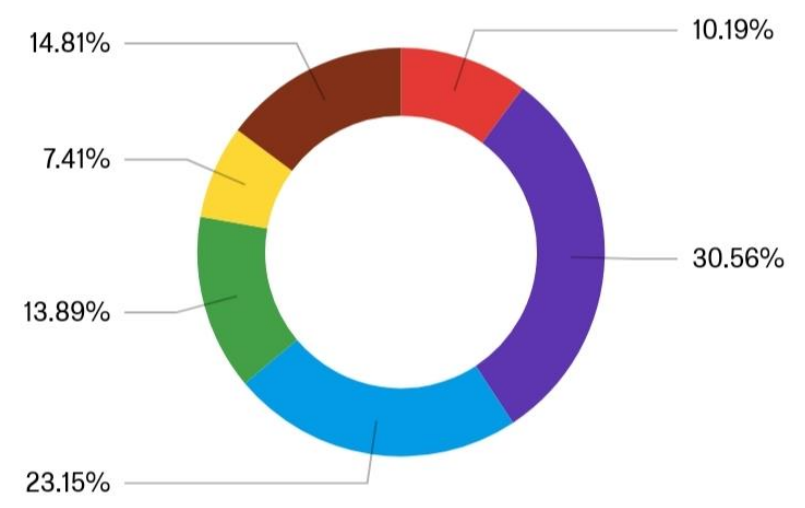

Prêmios e incentivos

Participação nos lucros

Participação nos resultados

Comissão de vendas

Prêmio por produtividade

Participação acionária

Fonte: Elaborado pelo autor, 2018. 
É válido destacarmos também a participação nos resultados da empresa, que possui um percentual de $23,15 \%$, valor bastante significativo. Este modelo faz com que o empregado receba um valor monetário no final do período estabelecido junto a organização, com o objetivo de aumentar a motivação do colaborador e ajudar o mesmo a alcançar suas metas.

O que surpreende neste gráfico é a pouca e quase ausente utilização de prêmio por produtividade e desempenho, que corresponde a $7,41 \%$ do total de indivíduos que recebem uma remuneração variável e/ou mista.

As próximas questões têm caráter um pouco mais técnico e teórico que as anteriores, foi perguntado aos participantes da pesquisa de campo se o mesmo acredita que a remuneração variável pode trazer mais motivação ao colaborador de uma organização. O resultado foi extremamente consolidado, não havendo dúvidas em relação a questão apresentada, cerca de $91,38 \%$ dos entrevistados concordaram totalmente $(39,23 \%)$ ou parcialmente $(52,15 \%)$ que os funcionários de uma organização se sentiriam mais motivados caso a mesma praticasse o uso da remuneração variável para com seus colaboradores. Os que discordam da situação apresentada somam $5,74 \%$ e os que se sentem indiferentes são apenas 2,87\%.

\section{Figura 8 - Remuneração variável X Motivação}

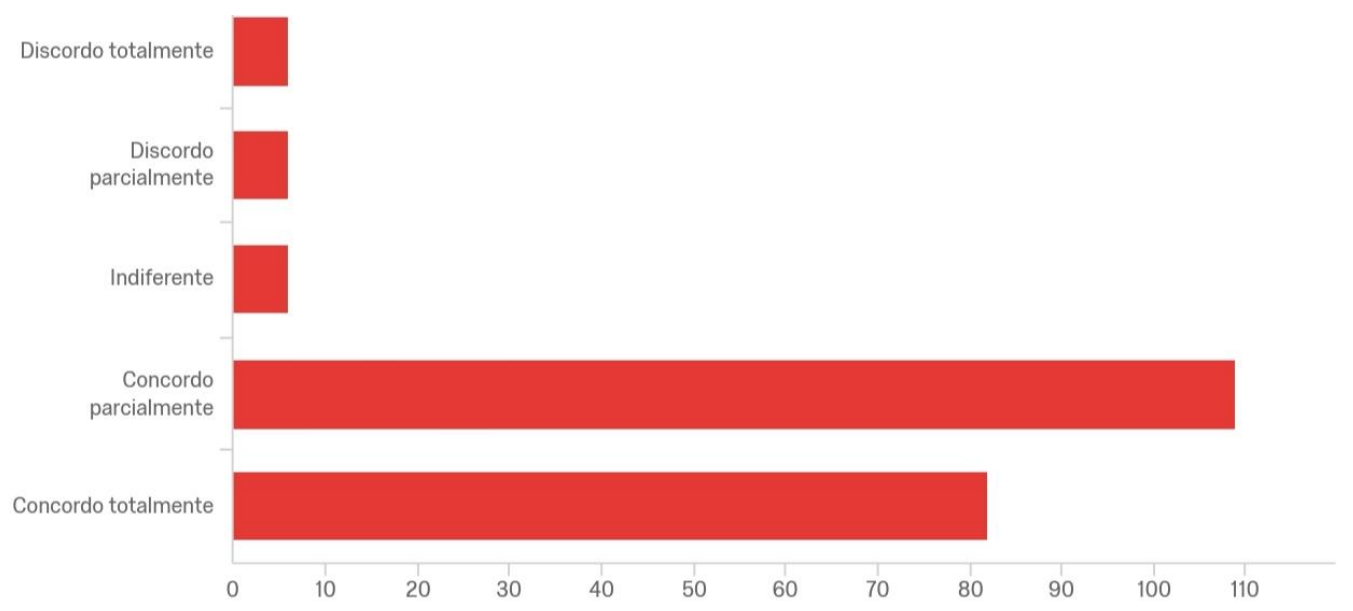

Fonte: Elaborado pelo autor, 2018. 
O último gráfico apresentado mostra a importância da motivação dos empregados em relação ao trabalho desempenhado em uma organização. Para a grande maioria, a motivação ela é influenciada pela remuneração variável e consequentemente traria resultados ainda melhores para a empresa, o que seria benéfico tanto para o colaborador quanto para a empresa, o funcionário poderia receber uma remuneração melhor e a companhia onde o mesmo trabalha teria um aumento em seus resultados. Vale ressaltar que, segundo a pirâmide das necessidades desenvolvida por Maslow, este tipo de motivação estaria atrelado a fatores de autorrealização e de estima, que mexem com a autoestima, confiança, respeito dos outros, crescimento, autocontrole, independência e desafios.

De acordo com a pergunta que aborda se o respondente acredita que uma organização pode melhorar seus resultados utilizando a remuneração variável como estratégia, ocorreu algo similar a questão anterior, cerca de $90,91 \%$ dos entrevistados concordam com a situação, para ser mais preciso $38,76 \%$ concordam totalmente e $52,15 \%$ concordam parcialmente, ou seja, a grande maioria enxerga a remuneração variável como boa estratégia a ser utilizada pelas empresas, corroborando as ideias que vimos dos autores no referencial teórico.

\section{Figura 9 - Remuneração variável X Resultados}

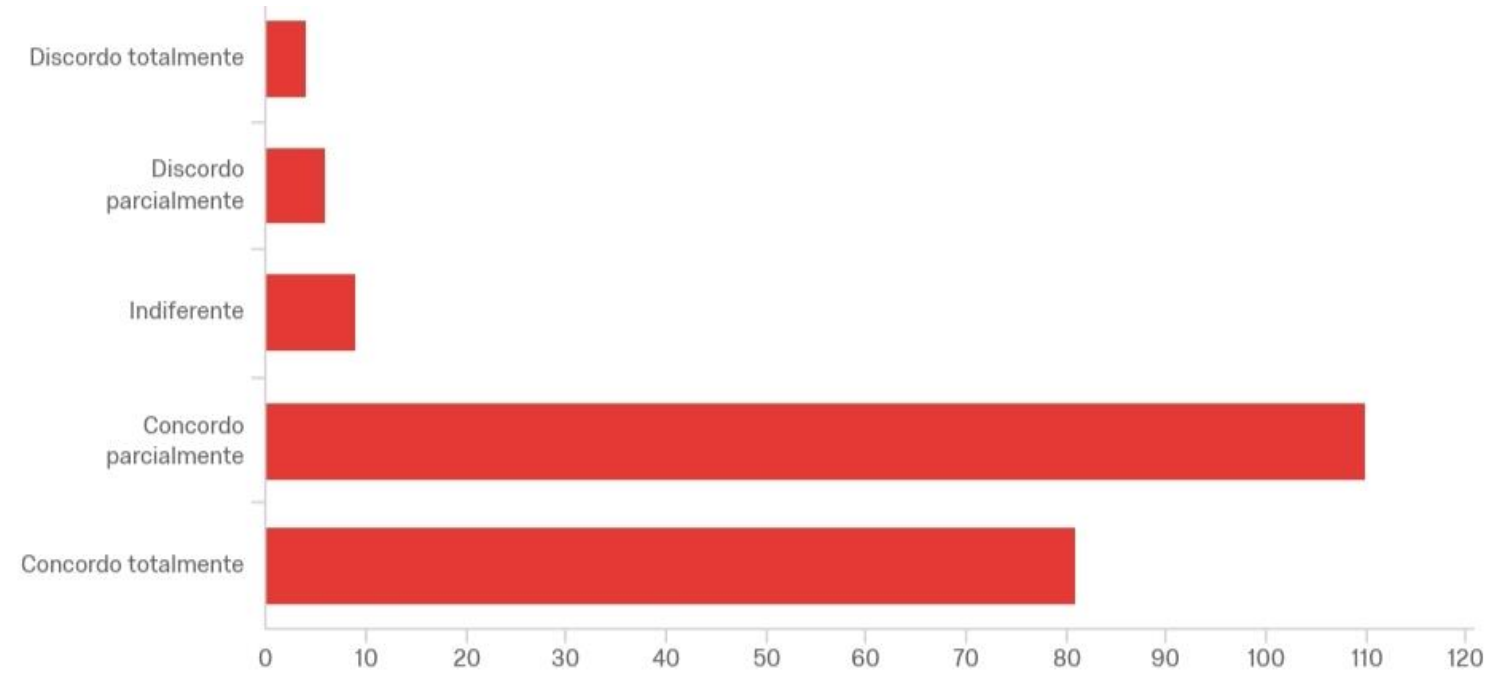

Fonte: Elaborado pelo autor, 2018. 
Esse tipo de remuneração pode melhorar diversos fatores que comprometem o resultado de uma organização. Segundo Dutra, o objetivo é incentivar os colaboradores a obterem um lucro acima do que os mesmos estariam dispostos caso não existisse a remuneração variável, ocasionando um aumento no resultado organizacional.

Por fim, 1,91\% discordam totalmente, 2,87\% discordam parcialmente e $4,31 \%$ acham a questão indiferente. É possível afirmar que para estas pessoas a remuneração fixa é mais vantajosa para as empresas.

Entretanto, o cenário muda apenas um pouco com relação a pergunta que avalia se o uso da remuneração variável nas organizações aumenta a competitividade interna entre os funcionários, isso porque 0 'concordo totalmente' fica como opção mais escolhida com 49,28\%, em seguida $41,15 \%$ dos entrevistados concordam parcialmente.

Figura 3 - Remuneração variável X Competitividade interna

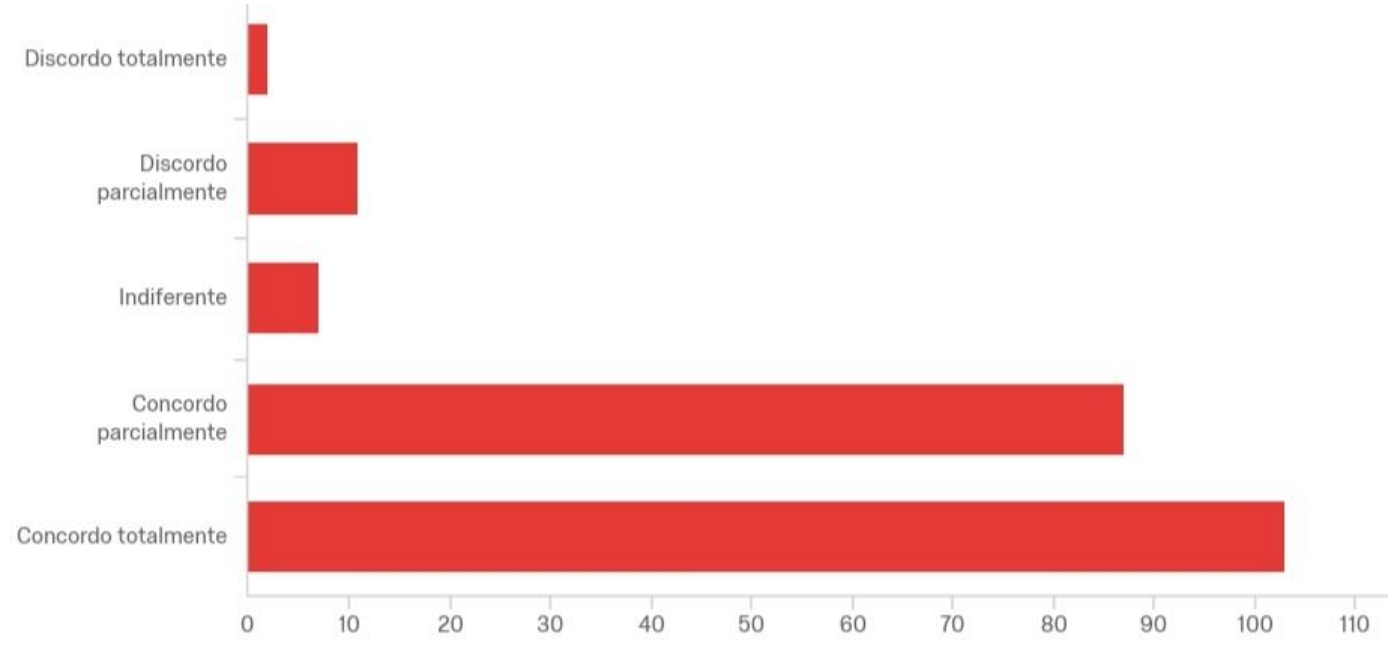

Fonte: Elaborado pelo autor, 2018.

Podemos enaltecer que a competitividade é fundamental no âmbito organizacional. Um ambiente competitivo colabora para o aumento da produtividade de trabalho. Os seres humanos possuem muitas vezes uma guerra de ego com o objetivo de sempre tentar ser melhor que o próximo. Fora que a competitividade desenvolve o colaborador profissionalmente, 
fazendo com que o mesmo busque melhores habilidades e competências para o sucesso da organização para a qual estão labutando. Vale ressaltar que segundo Chiavenato (2004), a organização deve sempre valorizar e manter pessoas que são destaque e que trazem resultados satisfatórios à organização, aprimorando assim o capital humano de uma empresa.

Contudo, representado por $0,96 \%$, há quem acredite que a competitividade interna fruto da remuneração variável não aumente de forma alguma. Existe também quem discorda parcialmente da situação apresentada, que são $5,26 \%$ e por fim quem acredita que seja indiferente, $3,35 \%$.

Em relação a pergunta se o entrevistado acredita que a avaliação de desempenho é a melhor forma de dar suporte a uma remuneração variável mais justa na empresa, o comportamento majoritário seguiu às três perguntas anteriores, onde $31,58 \%$ concordaram totalmente e $45,45 \%$ concordaram parcialmente. Contudo, podemos observar que a soma destas duas opções foi de $77,03 \%$. Consequentemente, houve um aumento das pessoas que discordaram, sendo elas $6,22 \%$ que discordaram totalmente, $13,88 \%$ que assinalaram 'discordo parcialmente' e $2,87 \%$ marcaram 'indiferente'.

Figura 11 - Remuneração variável X Avaliação de desempenho

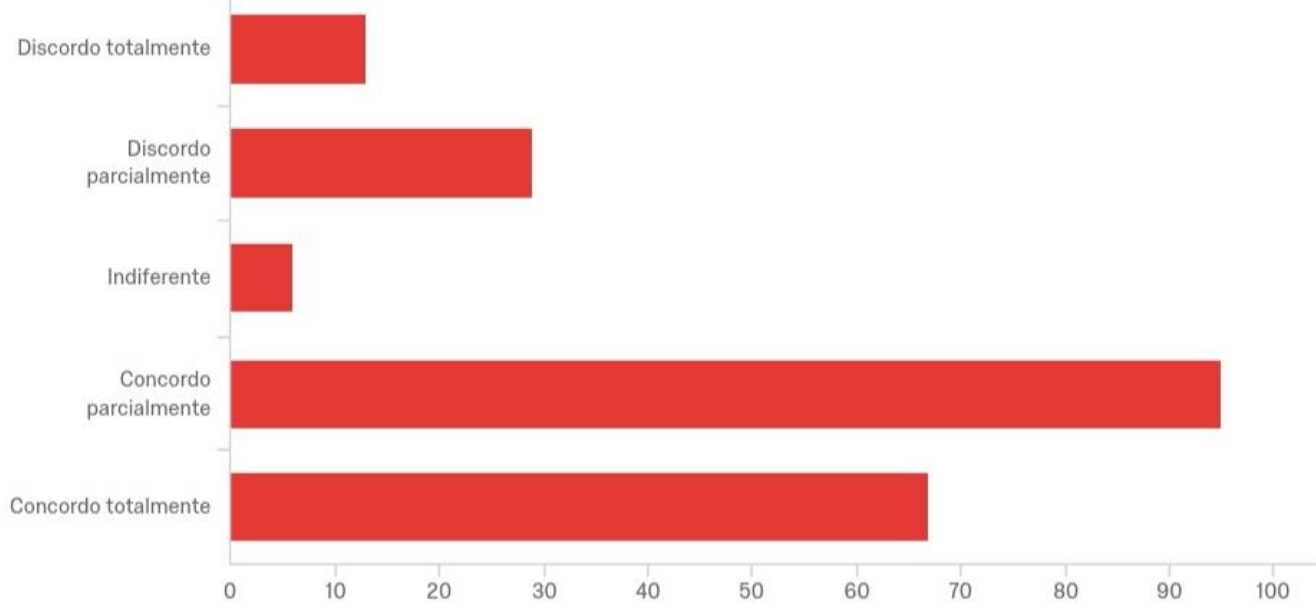

Fonte: Elaborado pelo autor, 2018. 
Nota-se que outros fatores também possuem sua parcela de importância ao auxiliar a remuneração variável de uma organização, deixando claro que a amostra nos mostra que o desempenho tem papel protagonista nesta situação.

Podemos enaltecer que Lawler (2000) destacou que o elemento desempenho é de suma importância para motivar os empregados. 0 reconhecimento explícito por parte da empresa é fruto de um bom desempenho gerado pelo funcionário, melhorando a eficácia da empresa. Para o autor seria mais justo e motivador.

$\mathrm{Na}$ pergunta de número 10 , foi requisitado que o respondente escolhesse três alternativas. Contudo, para nosso esclarecimento de qual fator seria mais relevante dentre os escolhidos, foi feita uma multiplicação simples, onde o fator de maior importância foi multiplicado por 3 , já o segundo elemento mais importante foi multiplicado por 2 e a de menor importância dentre as três alternativas escolhidas foi multiplicado por 1 . Com isso, podemos verificar qual fator é mais relevante na percepção dos entrevistados. No caso a 'colocação' dos elementos coincidiu com o número de 'votos totais' recebidos, entretanto isso poderia não ter acontecido, variando pelo peso de cada classificação. Verificamos que os principais fatores que satisfazem os empregados de uma empresa são, respectivamente: reconhecimento profissional, ambiente de trabalho e salário.

\section{Tabela 1 - Satisfação no trabalho}

\begin{tabular}{|l|c|c|c|c|c|c|}
\hline & $\begin{array}{c}\text { Votos } \\
\text { totais }\end{array}$ & $\begin{array}{c}\text { Importância +++ } \\
\text { Peso 3 }\end{array}$ & $\begin{array}{c}\text { Importância ++ } \\
\text { Peso 2 }\end{array}$ & $\begin{array}{c}\text { importância + } \\
\text { Peso 1 }\end{array}$ & $\begin{array}{c}\text { Fatores } \\
\text { Multiplicados }\end{array}$ & $\begin{array}{c}\text { Colocação } \\
\text { geral }\end{array}$ \\
\hline Ambiente de trabalho & 116 & 41 & 39 & 36 & 237 & 2 \\
\hline Reconhecimento profissional & 130 & 54 & 43 & 33 & 281 & 1 \\
\hline Atividade executada & 82 & 30 & 27 & 25 & 169 & 4 \\
\hline Salário & 106 & 38 & 33 & 35 & 215 & 3 \\
\hline Cumprimento de metas & 34 & 9 & 12 & 13 & 64 & 6 \\
\hline Investimento da empresa em cursos & 13 & 1 & 5 & 7 & 20 & 10 \\
\hline Promoções de cargo & 31 & $\mathbf{7}$ & 10 & 14 & 55 & 7 \\
\hline Colegas de trabalho & 28 & 6 & 9 & 13 & 49 & 8 \\
\hline Aprender coisas novas & 66 & $\mathbf{2 1}$ & $\mathbf{2 3}$ & $\mathbf{2 2}$ & 131 & $\mathbf{5}$ \\
\hline Infraestrutura/Lazer & 18 & 1 & 7 & 10 & 27 & 9 \\
\hline
\end{tabular}

Fonte: Elaborado pelo autor, 2018. 
Ao analisar esta primeira colocação do fator 'reconhecimento profissional', podemos constatar que o mesmo está atrelado aos fatores motivacionais de Frederick Herzberg, onde a existência deste componente motiva ainda mais o colaborador. Já a ausência do mesmo não significa que irá desmotivar o funcionário para exercer sua função.

Já a segunda colocação, que foi ocupada pelo 'ambiente de trabalho', podemos observar que o mesmo é fundamental para a satisfação do empregado. O meio que o funcionário está inserido é reflexo do resultado de suas principais funções e atividades dentro da organização. Se o ambiente organizacional não estiver em ordem, a tendência é não motivar o colaborador.

Por fim, em terceiro lugar está o 'salário', fator que para muitos ainda é o principal elemento que satisfaz um indivíduo dentro de uma organização. O salário é um componente que faz parte dos fatores higiênicos de Herzberg, talvez a explicação da remuneração variável ser pouco utilizada se dá por este fato curioso que é o tamanho da importância que os entrevistados deram a este elemento.

\section{Figura 4 - Vantagens da remuneração tradicional}

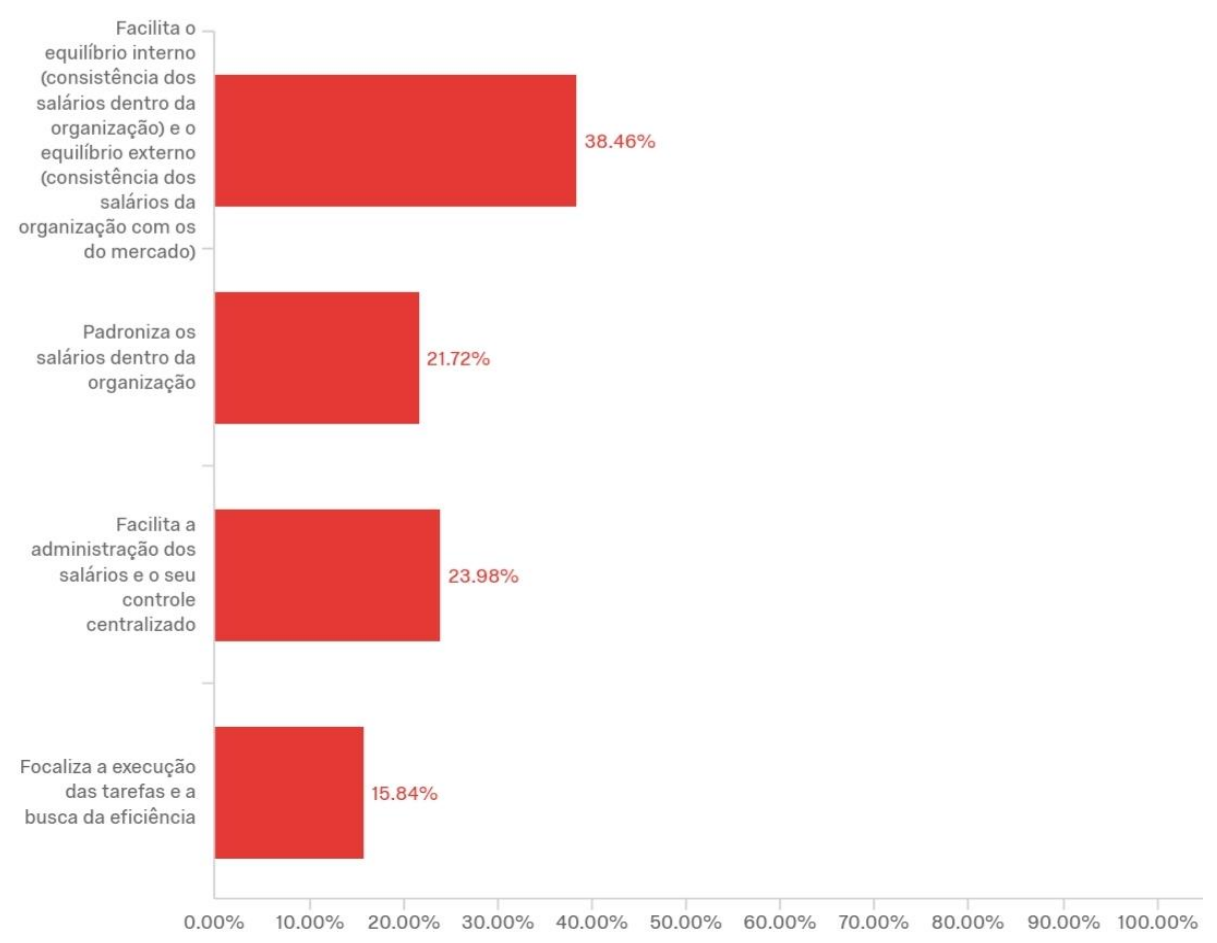

Fonte: Elaborado pelo autor, 2018. 
Nesta etapa final da pesquisa os entrevistados definiram a alternativa que eles mais consideram. Vamos analisar as principais vantagens e desvantagens tanto da remuneração tradicional quanto da remuneração variável.

A primeira pergunta desta sequência (figura 12) é sobre a vantagem que o respondente acredita que a remuneração tradicional possui. A alternativa que foi mais assinalada com $38,46 \%$ foi 'facilita 0 equilíbrio interno e o equilíbrio externo'. Ou seja, a comparação internamente e para com as outras empresas a respeito da remuneração paga aos funcionários é fator relevante que deve ser considerado pelas organizações, quando forem planejar uma estratégia de remuneração.

Já a segunda pergunta desta sequência, aborda as desvantagens que a remuneração tradicional apresenta. Podemos destacar que a maior parte dos entrevistados acreditam que este sistema remunera os indivíduos em função do tempo disponibilizado e não pelo desempenho ou alcance das metas ou resultados (46,19\%). Segundo Neto, o fato desse sistema tratar tudo de forma homogênea, ou seja, não levar em consideração as particularidades de cada cargo e função, torna esse modelo falho.

Figura 5 - Desvantagens da remuneração tradicional

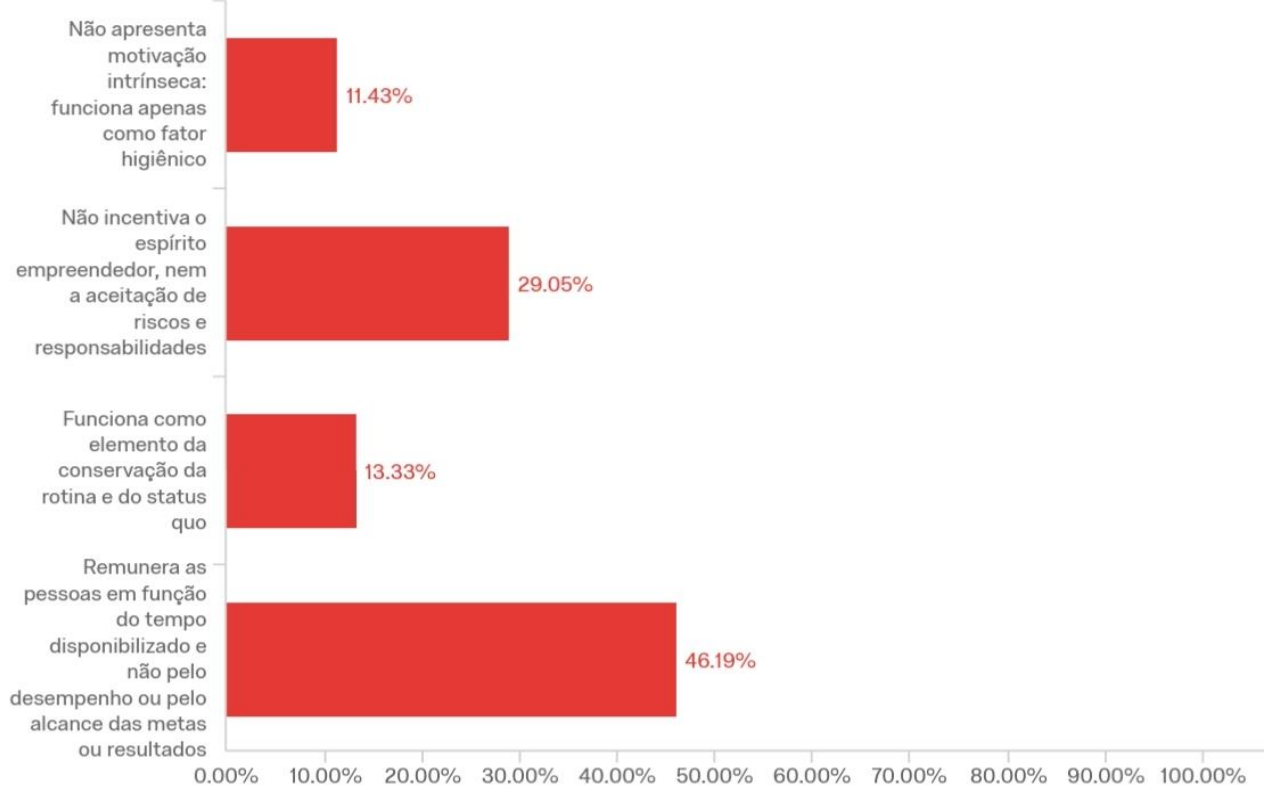

Fonte: Elaborado pelo autor, 2018. 
Isso resulta em uma má eficácia do sistema, pois as pessoas que têm sempre um alto nível de desempenho, entregam mais a organização. Fato que é pouco explorado por esse tipo de estratégia utilizada na maioria das instituições.

Outro elemento que merece destaque para os respondentes é ausência de incentivo do espírito de pertencimento da causa, que ficou com 29,05\%, o funcionário não se sente proprietário da situação, fazendo com que o mesmo não se empenhe o máximo que ele pode.

Agora em relação as vantagens que a remuneração variável apresenta ao sistema como um todo, podemos enaltecer que os respondentes acreditam que o principal fator que esse tipo de sistema possa oferecer é em relação aos colaboradores se sentirem mais motivados, com $47,62 \%$, ou seja quase a metade dos entrevistados, uma porcentagem extremamente relevante. Isso significa que as organizações precisam mudar o foco e englobar esse fator o quanto antes quando se trata da estratégia a ser utilizada. Esta deve ser bem embasada para que o colaborador esteja sempre motivado a exercer suas atividades e funções.

Figura 14 - Vantagens da remuneração variável

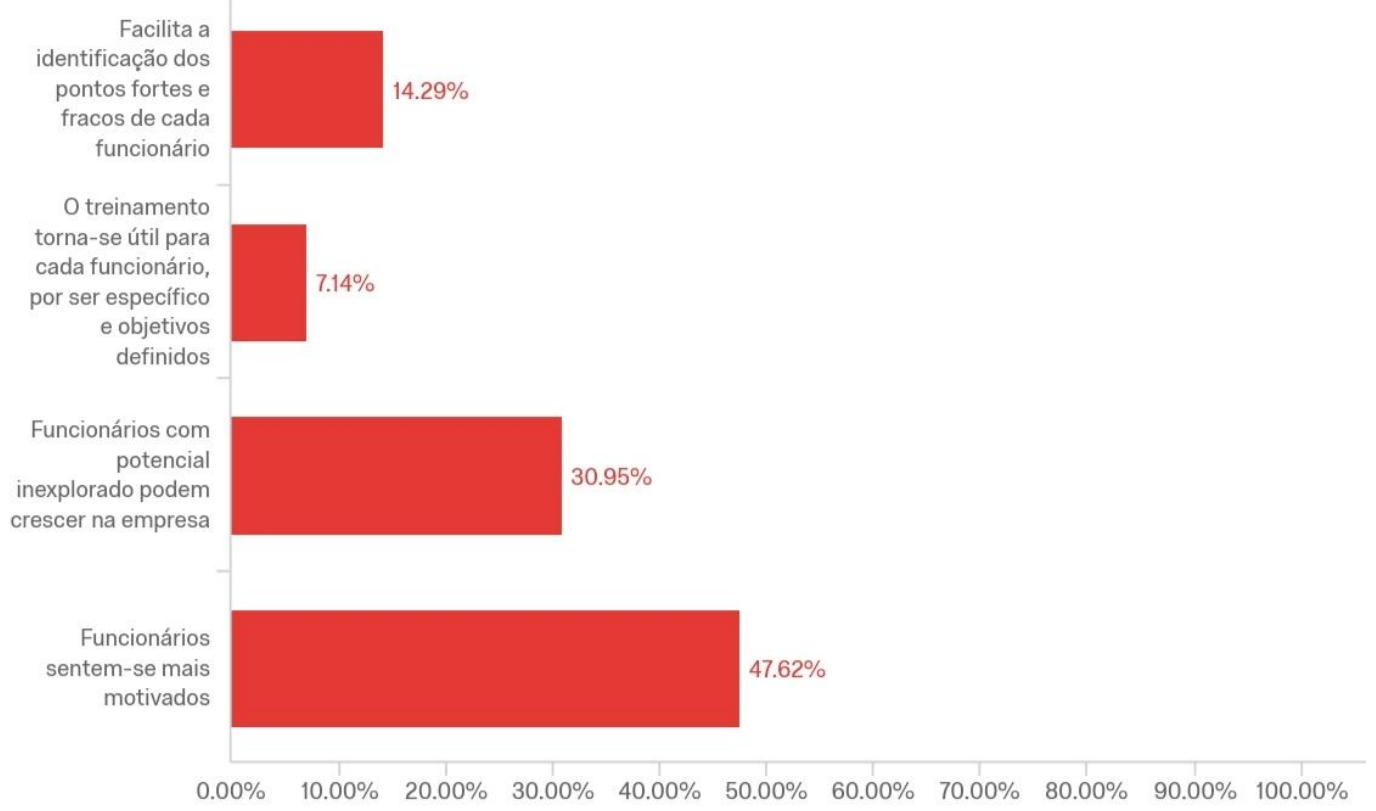

Fonte: Elaborado pelo autor, 2018. 
Podemos verificar que o último gráfico apresentado nos mostra outro dado a ser observado pelas empresas, que são os funcionários com potencial pouco explorados e que os mesmos podem crescer muito se houver algum fator que possa torná-los verdadeiros talentos. Esta alternativa foi assinalada por $30,95 \%$ dos entrevistados. Com o uso da estratégia da remuneração variável, esse gap de empregados que são mal explorados pode ser melhorado. O que resultaria em uma melhora nos resultados das corporações.

Por fim, chegamos a última pergunta respondida pelos entrevistados, que trata das desvantagens que a remuneração traz ao meio organizacional. Esta provavelmente é a pergunta-chave que responde o fato da maioria das empresas não utilizarem este tipo de estratégia em suas instituições.

\section{Figura 6 - Desvantagens da Remuneração variável}

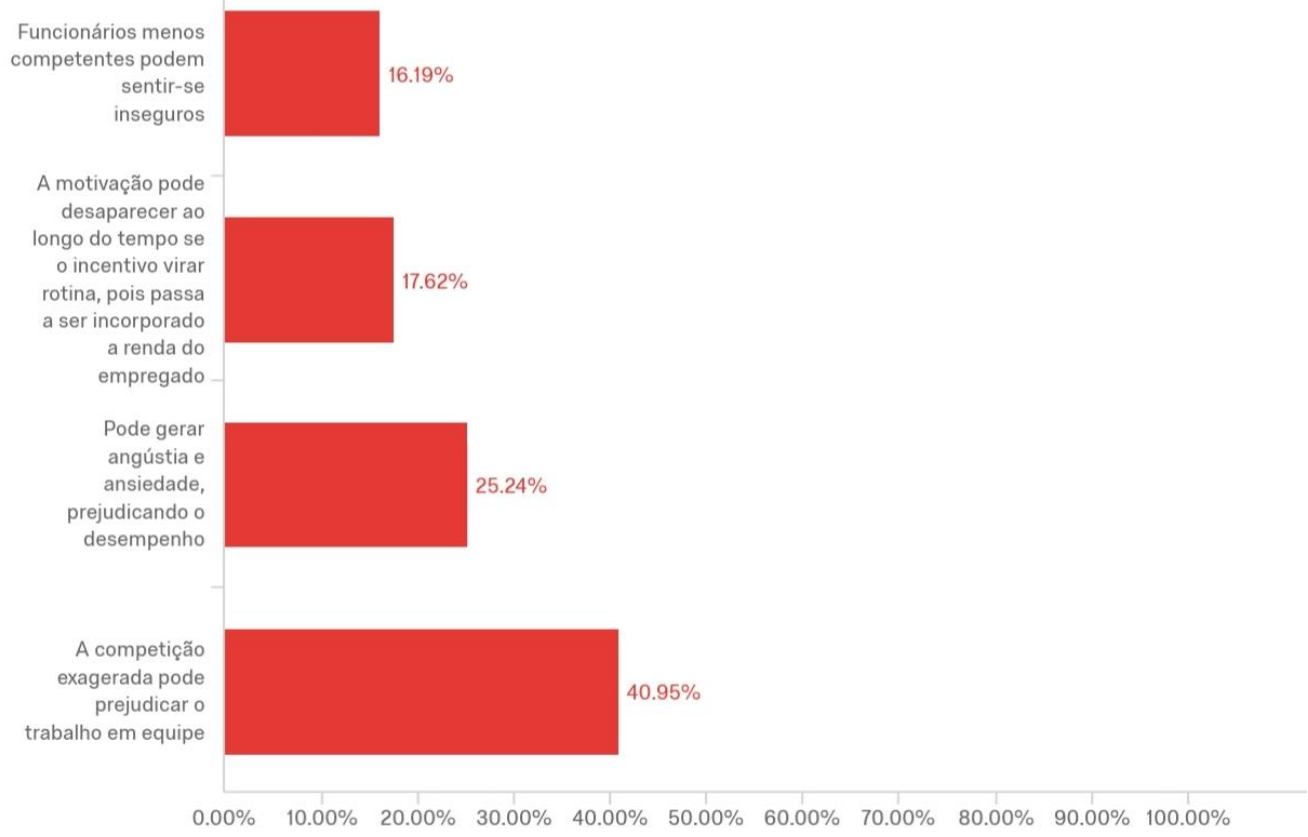

Fonte: Elaborado pelo autor, 2018.

Como podemos verificar, a alternativa que ficou com a maior parte da escolha dos entrevistados foi 'a competição exagerada pode prejudicar o trabalho em equipe', com 40,95\%. Sem dúvidas é um elemento que 
deve ser tratado com muita cautela pelas empresas, porque pode resultar em práticas de caráter imoral de um indivíduo e contaminar a toda equipe que está trabalhando com o mesmo, ou seja, o dano causado pode vir a ser muito grande. Entretanto, é total responsabilidade da organização para não deixar que isso aconteça. A remuneração variável deve ser bem planejada justamente para evitar esse tipo de situação.

Outro fato que deve ser destacado é a situação do colaborador fazer apenas as coisas que influenciam na remuneração variável. O indivíduo pode ter atitudes que serão prejudiciais a empresa, com o objetivo de melhorar apenas a remuneração a ser recebida por ele, no final do período trabalhado. Esse tipo de situação pode ser evitado caso o planejamento da estratégia do uso da remuneração varável seja extremamente bem elaborado e pensado, prevendo qualquer tipo de situação maléfica que possa vir a acontecer. 


\section{Conclusões}

Podemos verificar ao longo do presente trabalho o tamanho da importância que o assunto tem nos dias de hoje. Cada dia que passa constatamos que é mais difícil as empresas se destacarem uma das outras sem uma grande inovação. Com o uso da estratégia da remuneração variável é possível tornar isto como uma vantagem competitiva à organização, melhorando assim os resultados da mesma.

A partir do referencial teórico, podemos notar a importância da motivação dos funcionários para desempenharem suas respectivas funções nas instituições onde trabalham, fator que deve muito ser explorado ainda mais pela academia, visando sempre contribuir para construirmos melhores organizações. Isso pode ser explicado pelo fato do capital humano ser o principal elemento que compõe uma empresa, fazendo a mesma crescer de forma exponencial.

A realização da pesquisa de campo foi fundamental para melhor retratar o que de fato está acontecendo no nosso mercado de trabalho, corroborando as teorias vistas no referencial teórico. Vimos que a grande maioria dos entrevistados têm plena consciência da importância que a remuneração variável pode nos proporcionar, variando desde um aumento na satisfação do colaborador até resultados melhores que uma organização pode adquirir por meio desta estratégia.

Há alguns pontos que seria importante destacar, tendo em vista a análise feita na pesquisa. O primeiro é a respeito do tamanho da importância que o salário tem na percepção dos entrevistados. Como esse fator é considerado higiênico, talvez explica o fato de as empresas ainda não terem aderido ao tipo de remuneração variável. O que é algo contraditório, considerando que a maioria dos respondentes pensa que esse tipo de estratégia seria melhor. Vale lembrar que esse modelo está alinhado aos fatores motivacionais de Herzberg. 
Outro tópico que deve ser ressaltado é o cuidado que as empresas precisam tomar ao fazerem uso da remuneração variável. Esse modelo é necessário ser muito bem estruturado para não ocorrerem situações que podem vir a prejudicar a própria instituição, como por exemplo um colaborador tomar decisões que vá lesar a organização visando o aumento do que irá receber ao final do respectivo tempo trabalhado.

Podemos concluir que a associação de uma remuneração variável seria de fato mais motivador aos funcionários de uma organização porque estas satisfazem melhor as necessidades dos colaboradores perante a empresa. Por fim, enaltecemos que a remuneração variável incentiva o desempenho dos empregados e ao gerar o desenvolvimento dos potenciais talentos individuais resulta no capital intelectual da empresa. 


\section{Referências Bibliográficas}

BASTOS,VL.T.N.Motivação no trabalho,2001. Trabalho monográfico apresentado como requisito parcial para obtenção do grau especialista em reengenharia e Gestão de RH.Disponível em:<http//www.avm.edu.br/monopdf/19/vania\%20lucia\%20tortora\%20mag alhaes\%20bastos.pdf> Acesso em 09 de outubro de 2018.

BERNARDO,M.P.Motivação no trabalho,2015. Artigo apresentado como requisito parcial para obtenção do título de especialista em Gestão de Qualidade, do MBA em Gestão da Qualidade, da Universidade Federal do Paraná.Disponível

em:<https://acervodigital.ufpr.br/bitstream/handle/1884/52465/R\%20-

$\% 20 \mathrm{E} \% 20$

\%20MARLONN\%20PORTO\%20BERNARDO.pdf?sequence=1\&isAllowed $=y>$ Acesso em 09 de Outubro de 2018.

CARNEVALLI.J.A; MIGUEL.P.A.C.DESENVOLVIMENTO DA PESQUISA DE CAMPO, AMOSTRA E QUESTIONÁRIO PARA REALIZAÇÃO DE UM ESTUDO TIPO SURVEY SOBRE A APLICAÇÃO DO QFD NO BRASIL.2001.

Disponível em:<http://www.abepro.org.br/biblioteca/enegep2001 tr21 0672.pdf.> Acesso em: 08 de novembro de 2018.

CHIAVENATO, Idalberto. Gestão de Pessoas: e o novo papel dos recursos humanos nas organizações. Rio de Janeiro: Elsevier, 2004. $259 \mathrm{p}$.

Recursos Humanos: o capital humano das organizações. 8.ed. São Paulo: Atlas, 2004. 515p.

CUNHA,J.V.A,et al.Doutores em Ciências Contábeis: Análise sob a Óptica da Teoria do Capital Humano, 2010.Disponível em: <http://www.scielo.br/pdf/rac/v14n3/v14n3a09> Acesso em 12 de Outubro de 2018.

DALFOVO.M.S; LANA.R.A; SILVEIRA.A. Métodos quantitativos e qualitativos: um resgate teórico. 2008. Disponível em:< file://C:/Users/Vitor/Downloads/MONOGRAFIAS\%20M\%C3\%89TODOS\% 20QUANTITATIVOS\%20E\%20QUALITATIVOS.pdf>. Acesso em: 05 de novembro de 2018.

DIAS, A.L: CAMARA,D.S;NASCIMENTO,R.O. Avaliação de desempenho: Fatores que resultam em implicações negativas da avaliação de desempenho funcional associada ao programa GHF da CHESF,2003.Monografia apresentada ao curso de Especialização em 
Administração da Universidade Federal da Bahia, como requisito para obtenção do grau em Especialista em Administração.Disponível em: <http://www.adm.ufba.br/sites/default/files/publicacao/arquivo/avaliacao_d e_desempenho.pdf> Acesso em 13 de Outubro de 2018.

DUTRA, Joel S. Gestão de pessoas - Modelo, processos, tendências e perspectivas. Rio de janeiro. Atlas, 2016. 211 p. 212p.

FAVARIM, Flávia N. Remuneração e Salário: Uma abordagem jurídico/administrativa. Revista de Ciências Gerenciais, v. 15, n.21, ano 2011.

FLANNERY, T. P.; HOFRICHTER, D.; PLATTEN, P. E. Pessoas, desempenho e salários: as mudanças na forma de remuneração nas empresas. São Paulo: Futura, 1997.

FONSECA, J.J.S. Metodologia da Pesquisa Científica. 2002.

FROHMAN, Mark A. Unleash urgency and action, Industry Week, v. 245, n. 20, p. 13-23, November. 1996.

GOMES, R. A análise de dados em pesquisa qualitativa .In: MINAYO, M. C (organizadora).Pesquisa Social Teoria, Método e Criatividade. $22^{\circ}$ Ed. Petrópolis: Editora Vozes, 2003.

HAMPTON, David R. Administração: comportamento organizacional. São Paulo: Makron Books, 1990.

JABER,B. O que é capital humano e como ele influencia nos resultados da empresa?, 2018. Disponível em: $<$ http//www.xerpa.com.br/blog/capital-humano/> Acesso em: $10 \mathrm{de}$ Outubro de 2018.

LAWLER,E.E. Pay can be achange agent. Complensation \& Benefits Management, Greenvale, v 16, n 3, pág. 23-26, 2000.

MARRAS, Jean Pierre. Remuneração estratégica. 2012. $<$ https://books.google.com.br/books?hl=pt-

BR\&Ir=\&id=P KbaeW90MEC\&oi=fnd\&pg=PR1\&ots=AiPORrJtWR\&sig=N vRUZiTBqSP0Cvj8ISPoQ4-hzs\#v=onepage\&q\&f=false $>$ Acesso em 29 de setembro de 2018.

MARTINS, Sérgio P. Direito do Trabalho. 24.ed. São Paulo: Atlas, 2008 862p.

MARTINS.S.S; VERIANO.C.E, A remuneração flexível como componente da gestão de salários. 2004. Disponível em:< http://www.fgv.br/rae/artigos/revista-rae-vol-44-num-0-ano-2004-nid45582/>. Acesso em 05 de novembro de 2018. 
MENDONÇA.A.L; MAIA.M.C, GOÉS.P. Estudo de uma metodologia de capacitação de professores no uso de tecnologias educacionais. 2004. Disponível em <http://www.abed.org.br/congresso2004/por/pdf/015-tc-a2.pdf>. Acesso em: 05 de novembro de 2018.

NETO,M.T.R. A remuneração variável na percepção dos empregados e suas conseqüências na motivação e no desempenho.2004. Tese apresentada ao Curso de Doutorado em Administração do Centro de PósGraduação e Pesquisas da Faculdade de Ciências Econômicas da Universidade Federal de Minas Gerais como requisito parcial à obtenção do título de Doutor em Administração.Disponível em: <http://www.bibliotecadigital.ufmg.br/dspace/bitstream/handle/1843/BUBD -9BFH7E/tese_m_rio_teixeira_reis_neto.pdf?sequence $=1>$ Acesso em Acesso em: 23 de Outubro de 2018.

RICHARDSON, R. (coord.) et al. Pesquisa social: métodos e técnicas. São Paulo: Atlas, 1989.

ROSA, F.D. Participação nos lucros e resultados: a grande vantagem competitiva.São Paulo: Atlas, 2000.

SAWREY, James M.; TELFORD, Charles W. Psicologia educacional. Rio de Janeiro: Livros Técnicos e Científicos, 1976.

SEBRAE. Micro e pequenas empresas correspondem a $27 \%$ do PIB do Brasil <http://www.sebrae.com.br/sites/PortalSebrae/ufs/mt/noticias/micro-epequenas-empresas-geram-27-do-pib-dobrasil,ad0fc70646467410VgnVCM2000003c74010aRCRD>. Acesso em: 23 de outubro de 2018.

SEVERINO,A.J. Educação, sujeito e história. Ed. Olho d'Água, 2002.

SOBRAL.F; PECI.A. Administração: teoria e prática no contexto brasileiro.São Paulo. Pearson, 2008.

TAVARES.F.P. Motivação e desmotivação sob 0 enfoque organizacional. $2004 . \quad$ Disponível em:< http://www.convibra.com.br/2004/pdf/31.pdf >.acesso em 05 de novembro de 2018.

TRIVIÑOS, A. N. S. Introdução à pesquisa em Ciências Sociais: a pesquisa qualitativa em educação. São Paulo: Atlas, 1987. 


\section{Anexo 1}

\section{Roteiro de Entrevista - Remuneração variável}

Apresentação:

Olá, tudo bem?

Meu nome é Victor, sou estudante do curso de Administração de Empresas da PUC-Rio. Estou fazendo uma pesquisa sobre a viabilidade estratégica da remuneração variável com indivíduos que estão no mercado de trabalho. A pesquisa é rápida e não irá demorar mais que 5 minutos

A participação nesta pesquisa é anônima e não produzira nenhum tipo de risco para as atividades de trabalho do respondente.

Desde já, agradeço sua participação!

Victor Felcman Adesse

Graduação em Administração de Empresas

PUC-Rio

Questão 01) Qual seu gênero?

( ) Feminino

( ) Masculino

( ) Outros

Questão 02) Qual sua faixa etária?

( ) Até 20 anos

( ) 21 a 25 anos

( ) 26 a 30 anos

( ) 31 a 35 anos

( ) 36 a 40 anos

( ) 41 a 45 anos

( ) 46 a 50 anos

( ) 51 a 55 anos

( ) 56 anos ou mais

Questão 03) Qual a posição do seu cargo na empresa que trabalha?

( ) Operacional

( ) Tático

( ) Estratégico 
Questão 04) Sua remuneração é fixa, variável ou mista?
( ) Fixa
( ) Variável
( ) Mista

Questão 05) Caso tenha marcado a opção variável ou mista na questão anterior, quais as formas dessa remuneração?
( ) Prêmios e incentivos
( ) Participação nos lucros
( ) Participação nos resultados
( ) Comissão de vendas
( ) Prêmio por produtividade
( ) Participação acionária

Questão 06) Você acredita que a remuneração variável pode trazer mais motivação ao colaborador de uma empresa?
( ) Discordo totalmente
( ) Discordo parcialmente
( ) Indiferente
( ) Concordo parcialmente
( ) Concordo totalmente

Questão 07) Você acredita que uma organização pode melhorar seus resultados utilizando a remuneração variável como estratégia?

( ) Discordo totalmente

( ) Discordo parcialmente

( ) Indiferente

( ) Concordo parcialmente

( ) Concordo totalmente

Questão 08) Você acredita que com o uso da remuneração variável nas empresas aumenta a competitividade interna entre os funcionários?
( ) Discordo totalmente
( ) Discordo parcialmente
( ) Indiferente
( ) Concordo parcialmente
( ) Concordo totalmente

Questão 09) Você acredita que a avaliação de desempenho é a melhor forma de dar suporte a uma remuneração variável mais justa na empresa?
( ) Discordo totalmente
( ) Discordo parcialmente
( ) Indiferente
( ) Concordo parcialmente
( ) Concordo totalmente

Questão 10) O que traz mais satisfação em seu trabalho? (Assinalar as 3 que mais considera, sendo 3 o fator que mais considera e 1 o fator que menos considera entre as 3 escolhidas) 
[ ] Ambiente de trabalho

[ ]Reconhecimento profissional

[ ] Atividade executada

[ ] Salário

[ ] Cumprimento de metas

[ ] Investimento da empresa em cursos

[ ] Promoções de cargos

[ ] Colegas de trabalho

[ ] Aprender coisas novas

[ ] Infraestrutura/lazer oferecido pela empresa

Questão 11) Qual vantagem você atribui a remuneração tradicional? (Definir a que mais considera)

( ) Facilita o equilíbrio interno (consistência dos salários dentro da organização) e o equilíbrio externo (consistência dos salários da organização com os do mercado

( ) Padroniza os salários dentro de uma organização

( ) Facilita a administração dos salários e o seu controle centralizado

( ) Focaliza a execução das tarefas e a busca da eficiência

Questão 12) Qual desvantagem você atribui a remuneração tradicional? (Definir a que mais considera)

( ) Não apresenta motivação intrínseca: funciona apenas como fator higiênico

( ) Não incentiva o espírito empreendedor, nem a aceitação de riscos e responsabilidades

( ) Funciona como elemento da conservação da rotina e do status quo

( ) Remunera as pessoas em função do tempo disponibilizado e não pelo desempenho ou pelo alcance das metas ou resultados

Questão 13) Qual vantagem você atribui a remuneração variável?

( ) Facilita a identificação dos pontos fortes e fracos de cada funcionário

( ) O treinamento torna-se útil para cada colaborador, por ser específico e objetivos definidos

( ) Funcionários com potencial inexplorado podem crescer na empresa

( ) Funcionários sentem-se mais motivados

Questão 14) Qual desvantagem você atribui a remuneração variável? (Definir a que mais considera)

( ) Funcionários menos competentes podem sentir-se inseguros

( ) A motivação pode desaparecer ao longo do tempo se o incentivo virar rotina, pois passa a ser incorporado a renda do empregado

( ) Pode gerar angústia e ansiedade, prejudicando o desempenho

( ) A competição exagerada pode prejudicar o trabalho em equipe 